John Carroll University

Carroll Collected

Biology

$12-2008$

\title{
The Biological Soil Crusts of the San Nicolas Island: Enigmatic Algae from a Geographically Isolated Ecosystem
}

Valerie R. Flechtner

John Carroll University, vflechtner@jcu.edu

Jeffrey R. Johansen

John Carroll University, johansen@jcu.edu

Jayne Belnap

Follow this and additional works at: http://collected.jcu.edu/biol-facpub

Part of the Biology Commons

\section{Recommended Citation}

Flechtner, Valerie R.; Johansen, Jeffrey R.; and Belnap, Jayne, "The Biological Soil Crusts of the San Nicolas Island: Enigmatic Algae from a Geographically Isolated Ecosystem" (2008). Biology. 4.

http://collected.jcu.edu/biol-facpub/4 


\title{
THE BIOLOGICAL SOIL CRUSTS OF THE SAN NICOLAS ISLAND: ENIGMATIC ALGAE FROM A GEOGRAPHICALLY ISOLATED ECOSYSTEM
}

\author{
Valerie R. Flechtner1,3, Jeffrey R. Johansen ${ }^{1}$, and Jayne Belnap²
}

\begin{abstract}
AвsтRACT.-Composite soil samples from 7 sites on San Nicolas Island were evaluated quantitatively and qualitatively for the presence of cyanobacteria and eukaryotic microalgae. Combined data demonstrated a rich algal flora with 19 cyanobacterial and 19 eukaryotic microalgal genera being identified, for a total of 56 species. Nine new species were identified and described among the cyanobacteria and the eukaryotic microalgae that were isolated: Leibleinia edaphica, Aphanothece maritima, Chroococcidiopsis edaphica, Cyanosarcina atroveneta, Hassallia californica, Hassallia pseudoramosissima, Microchaete terrestre, Palmellopsis californicus, and Pseudotetracystis compactis. Distinct distributional patterns of algal taxa existed among sites on the island and among soil algal floras of western North America. Some algal taxa appeared to be widely distributed across many desert regions, including Microcoleus vaginatus, Nostoc punctiforme, Nostoc paludosum, and Tolypothrix distorta, Chlorella vulgaris, Diplosphaera cf. chodatii, Myrmecia astigmatica, Myrmecia biatorellae, Hantzschia amphioxys, and Luticola mutica. Some taxa share a distinctly southern distribution with soil algae from southern Arizona, southern California, and Baja California (e.g., Scenedesmus deserticola and Eustigmatos magnus). The data presented herein support the view that the cyanobacterial and microalgal floras of soil crusts possess significant biodiversity, much of it previously undescribed.
\end{abstract}

Key words: soil algae, microbiotic crusts, cyanobacteria, microalgae, biodiversity, San Nicolas Island, desert.

Arid and semiarid soils represent challenging habitats for microorganisms because of high light intensity, low water availability, and extreme temperature variability. Yet diverse microbial communities exist in these soils forming microbiotic crusts consisting of prokaryotic and eukaryotic algae, lichens, nonlichenized fungi, bryophytes, and invertebrates (reviewed by Flechtner 1999, 2007, Bhatnagar and Bhatnagar 2005, Flechtner et al. 2005, Lewis 2007). Floristic studies done during the 1980s, primarily on soils of the Colorado Plateau and Great Basin, reported diverse diatom and cyanobacterial populations (reviewed by Johansen 1993), but little diversity was reported among nondiatom eukaryotic algae. The first comprehensive study of algae from a single terrestrial site was that of Johansen et al. (1993), who identified 90 different algal taxa from a sagebrush steppe community in the Lower Columbia Basin (WA). More recent studies have revealed highly diverse algal populations in crusts sampled from hot arid and cold semiarid deserts (Flechtner et al. 1998, Flechtner 1999, Lewis and Lewis 2005, Lewis 2007). Some of the sites were rich in both cyanophytes (prokaryotic) and eukaryotic algae, while others, particularly those located in hot deserts, yielded only eukaryotic algae. These studies and others challenge the conventional wisdom that little diversity exists among the nondiatom eukaryotic algae isolated from desert soils. New cyanobacterial genera (Flechtner et al. 2002, Reháková et al. 2007) and new species (Flechtner et al. 1998, Lewis and Flechtner 2002, 2004) have been identified in several studies.

San Nicolas Island is the largest of the Channel Islands lying off the coast of California. It offers the opportunity to examine the algal flora in a geographically isolated locale. Our study consisted of 5 parts: (1) we quantified cyanobacteria and eukaryotic algae in 7 sites; (2) we determined the distribution of taxonomic groups across the sites; (3) we searched for putative new algal species; (4) we examined soil chemistry characteristics of each site; and (5) we compared the species composition of these sites with that of a previously studied site in Baja California, Mexico. Our results support the view that the diversity of soil algae is greater than previously appreciated

\footnotetext{
${ }^{1}$ Department of Biology, John Carroll University, University Heights, OH 44118.

${ }^{2}$ U.S. Geological Survey, Southwest Biological Science Center, Canyonlands Research Station, Moab, UT 84532

${ }^{3}$ E-mail: flechtner@jcu.edu
} 

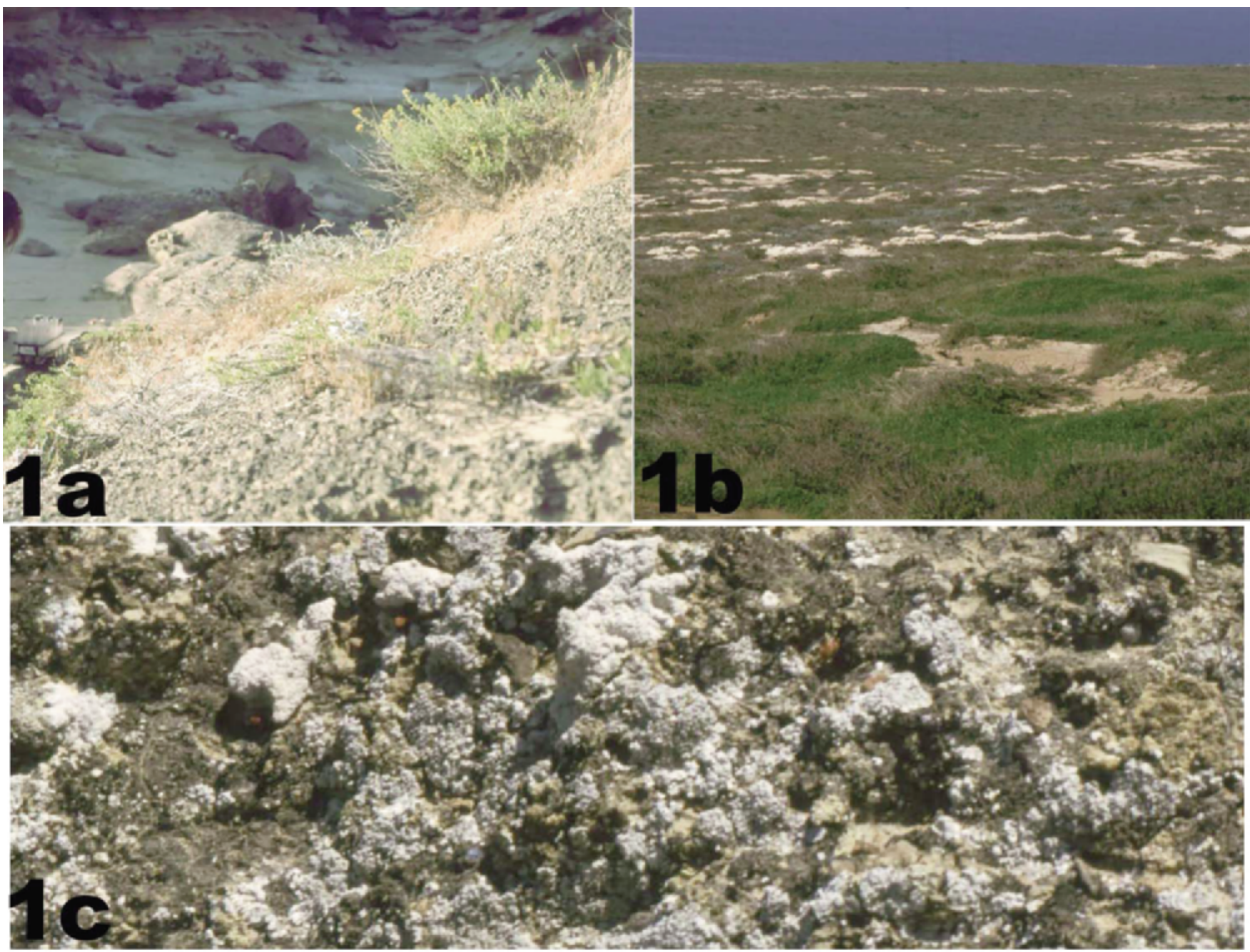

Fig. 1. Study sites on San Nicolas Island: a, sites 1-3 (CAS 1-3); b, sites 4-7 (CATS 1-4); c, microbiotic crust.

and that desert soils of North America contain numerous taxa new to science.

\section{Methods \\ Study Sites}

San Nicolas Island $\left(33.2^{\circ} \mathrm{N}, 119.2^{\circ} \mathrm{W}\right)$ is one of the most western of the Channel Islands. The average daily maximum and minimum temperatures calculated from records kept from 1948 to 1992 were 18.7 and $11.3{ }^{\circ} \mathrm{C}$, respectively. Several records of temperatures exceeding $38{ }^{\circ} \mathrm{C}$ exist, while no temperatures below $0{ }^{\circ} \mathrm{C}$ were reported. During the hottest months (June-October) average temperature maxima range from 17.0 to $22.0{ }^{\circ} \mathrm{C}$. Annual rainfall averages $201 \mathrm{~mm}$, with the greatest precipitation occurring from November through March. Humidity on the island is higher than that normally found in desert habitats; mean morning relative humidity was $81 \%$ and mean midday relative humidity was $64 \%$. The island is small and is continually fogged and sprayed by salt water.
Sites 1-3 (CAS 1-3) were located on the hillside slopes surrounding the island (Fig. 1a); sites 4-7 (CATS 1-4) were located in the center of the island (Fig. 1b). The soils of all sites had well-developed lichen crusts (Fig. 1c). Nitrogen fixation has been detected in the soils from site 2, but not from the other sites ( $\mathrm{J}$. Belnap unpublished data).

\section{Sample Collection}

Soil samples were collected on 7 July 1993 and stored dry and under refrigeration until analysis was initiated on 13 August 1993. At each site, 30 subsamples were collected and combined into a single composite sample.

At the time of plating, soil samples were crushed and mixed to produce a homogeneous sample. A 1-g subsample was removed and added to $99 \mathrm{~mL}$ sterile distilled water $\left(10^{2}\right.$ dilution); the sample was shaken vigorously 25 times and a 10 -fold dilution ( $10^{3}$ dilution) was prepared. Care was taken to shake the samples vigorously immediately prior to removing aliquots of $0.3 \mathrm{~mL}$ of the $10^{2}$ and $10^{3}$ dilutions, which were spread in triplicate on agar-solidified Z-8 
TABLE 1. Soil chemistry analysis data for 7 sites on San Nicolas Island, CA. Abbreviations: OM = organic matter; $\mathrm{PPM}=$ parts per million; $\mathrm{NO}_{3} \mathrm{~N}=$ nitrogen as nitrate; $\mathrm{P}=$ phosphorous; $\mathrm{K}_{\text {avail }}=$ available potassium; $\mathrm{K}=$ exchangeable potassium; $\mathrm{Ca}=$ exchangeable calcium; $\mathrm{Mg}=$ exchangeable magnesium; $\mathrm{Na}=$ exchangeable sodium. Site $1=$ hillside slope (CAS 1), site $2=$ hillside slope (CAS 2), site $3=$ hillside slope (CAS 3), site $4=$ island center (CATS 1 ), site $5=$ island center (CATS 2), site $6=$ island center (CATS 3), site $7=$ island center (CATS 4).

\begin{tabular}{|c|c|c|c|c|c|c|c|}
\hline \multirow[b]{2}{*}{ Parameter } & \multicolumn{7}{|c|}{ Sites } \\
\hline & 1 & 2 & 3 & 4 & 5 & 6 & 7 \\
\hline $\mathrm{pH}$ & 8.3 & 7.9 & 7.8 & 7.9 & 8.2 & 7.7 & 8.0 \\
\hline$\%$ Sand & 80.36 & 46.00 & 56.36 & 60.14 & 60.29 & 70.78 & 50.50 \\
\hline$\%$ Clay & 8.49 & 18.78 & 18.63 & 14.56 & 24.63 & 13.51 & 22.56 \\
\hline$\%$ Silt & 11.15 & 35.22 & 25.01 & 25.30 & 15.08 & 15.71 & 26.94 \\
\hline$\% \mathrm{OM}$ & 0.59 & 2.58 & 0.65 & 0.71 & 1.61 & 1.39 & 1.10 \\
\hline $\mathrm{PPM} \mathrm{NO} \mathrm{NO}_{3} \mathrm{~N}$ & 0.43 & 0.48 & 1.72 & 0.54 & 0.74 & 9.32 & 0.37 \\
\hline PPM P & 2.71 & 2.67 & 8.34 & 1.25 & 11.03 & 17.99 & 6.29 \\
\hline PPM K avail. & 147.2 & 140.8 & 342.4 & 147.2 & 272.0 & 173.9 & 217.6 \\
\hline PPM K & 40.0 & 90.0 & 280.0 & 70.0 & 290.0 & 228.3 & 260.0 \\
\hline PPM Ca & 3520 & 6050 & 6830 & 7130 & 9470 & 3087 & 10,250 \\
\hline PPM Mg & 120.0 & 210.0 & 350.0 & 210.0 & 440.0 & 207.0 & 410.0 \\
\hline PPM Na & 163.8 & 417.6 & 657.0 & 558.0 & 352.8 & 306.7 & 1830.6 \\
\hline
\end{tabular}

medium (Carmichael 1986) for cultivation and quantitation of cyanobacteria and on Bold's basal medium (BBM; Bold and Wynne 1978) for cultivation and quantitation of nondiatom eukaryotic algae. Plates were allowed to dry overnight. They were then sealed with parafilm and incubated in constant light at $20-23{ }^{\circ} \mathrm{C}$ until good growth had been obtained (3-6 weeks).

\section{Algal Identification}

Clonal isolates of nondiatom eukaryotic algae were prepared by picking isolated colonies from agar plates into $5 \mathrm{~mL}$ liquid $\mathrm{BBM}$ and incubating the cultures 2-4 weeks until good growth had been obtained. Identification was made on the basis of life history and morphological criteria using standard authoritative references (Komárek and Fott 1983, Ettl and Gärtner 1995). To characterize cyanophytes, we used wet mounts prepared directly from individual isolates or wet mounts prepared from wetted soil samples and incubated for 48-72 hours in the light. Cyanophytes were identified, based on cell and colony morphology, using standard references (Geitler 19301932, Desikachary 1959, Starmach 1966, Kantz and Bold 1969, Komárek and Anagnostidis 1998, 2005). The new classification scheme for the subclasses of cyanobacteria based on molecular and ultrastructural studies was followed (Hoffmann et al. 2005). The noteworthy change in this scheme is that the Chroococcales and Oscillatoriales in the old sense (Geitler 19301932) have been abandoned such that the
Synechococcineae and Oscillatoriineae now contain both coccoid and filamentous forms, based on phylogeny, cell division, and thylakoid structure. For diatom analysis, subsamples of each soil sample were removed, acid-cleaned, washed, and mounted into permanent diatoms slides following Johansen et al. (1982). An Olympus BH-2 photomicroscope with Nomarski DIC optics was used for all microscopic work; photographic records of taxa were made using Kodak PKL-135 film. Diatoms were identified as previously described (Johansen et al. 1993)

\section{Soil Chemistry}

Soil chemistry and physical analyses were conducted by the Soil Testing Laboratory at Brigham Young University using standard methods as previously described (Flechtner et al. 1998).

\section{Results}

\section{General Conclusions}

The 7 sites studied were quite variable in soil texture (Table 1), and consisted of loams (site 2), sandy loams (sites 3,4,6), sandy clay loams (site 5, 7) and loamy sand (site 1). The San Nicolas sites had higher levels of cations $\left(\mathrm{Na}^{+}, \mathrm{Mg}^{++}, \mathrm{Ca}^{++}, \mathrm{K}^{+}\right)$than sites we have previously examined from the Great Basin Desert, Colorado Plateau, and Mojave Desert (unpublished data), likely due to inputs of marine salts via ocean spray. Site 7 in particular had very elevated levels of sodium, with 1830 
TABLE 2. Concentration of eukaryotic algae and cyanobacteria in 7 sites on San Nicolas Island, CA. CFU/g = colony forming units per gram of soil.

\begin{tabular}{lcc}
\hline Site & $\begin{array}{c}\text { Eukaryotic algae } \\
\left(\mathrm{CFU} / \mathrm{g} \times 10^{4}\right)\end{array}$ & $\begin{array}{c}\text { Cyanobacteria } \\
\left(\mathrm{CFU} / \mathrm{g} \times 10^{5}\right)\end{array}$ \\
\hline 1 & 3.1 & 2.6 \\
2 & 3.1 & 2.2 \\
3 & 5.2 & 1.7 \\
4 & 0.3 & 1.9 \\
5 & 4.6 & 4.8 \\
6 & 6.6 & 2.9 \\
7 & 9.6 & 3.4 \\
\hline
\end{tabular}

ppm exchangeable $\mathrm{Na}^{+}$. Calcite was evident in field observations of this soil, and this was reflected in the elevated $\mathrm{Ca}^{++}$of the site (Table 1).

The range of algal concentration within the 7 study sites was $0.3 \times 10^{4}$ to $9.6 \times 10^{4}$ colony forming units (CFUs) per gram soil for eukaryotic algae to $1.7 \times 10^{5}$ to $3.4 \times 10^{5}$ CFUs per gram soil for cyanophytes (Table 2 ). The predominance of cyanophytes at all sites was confirmed from examination of wet mounts.

Thirty-two cyanophyte species belonging to 19 genera were identified (Table 3). Filamentous forms were observed more frequently than coccoid forms, particularly in sites 4-6. Microcoleus vaginatus, Hassallia pseudoramosissima, Tolypothrix distorta var. symplocoides, and members of the genus Nostoc were present in all 7 sites. Other taxa showed more narrow distribution; for example, while coccid cyanophytes were identified multiple times in sites $1-3$, very few coccoid cyanobacteria were identified in sites 4-7.

The relative distribution of cyanobacteria also differed among the sites. Members of the genera Hassallia and Microcoleus dominated in site 1 . Site 2 was noteworthy for the diversity of cyanophyte taxa present. It also had the highest concentration of Nostoc species. Leptolyngbya ssp. dominated in site 3 , and $T$. distorta var. symplocoides colonies outnumbered Nostoc colonies. Few Nostoc isolates were observed in site 4 . Site 5 had a rich flora of heterocytous cyanobacteria including Hassallia, Tolypothrix, and 4 species of Nostoc. Heterocytous algae dominated in site 6 . Site 7 was dominated by Leptolyngbya and Nostoc species; few Microcoleus filaments were observed.

The distribution of eukaryotic algae within the sites was less uniform than that of the cyanophytes, ranging from $3 \times 10^{3} \mathrm{CFUs}$ per gram soil in site 4 to $9.6 \times 10^{4} \mathrm{CFU}$ s per gram soil in site 6 . Of the 24 species identified, 14 were members of the Chlorophyta, 1 was a eustigmatophyte, 1 was a tribophyte, and 8 were diatoms (Table 4). Some taxa were ubiquitous. Diplococcus cf. chodatii, Hantzschia amphioxys, and Luticola mutica were found in all 7 sites while members of the genus Myrmecia, Bracteacoccus, and Eustigmatos magnus were found in 5 of the 7 sites. Other taxa were found in only 1 or 2 sites.

Based on cell characteristics and life history, 17 of the 21 taxa could be assigned with reasonable confidence to previously described species, with an additional 3 taxa closely comparable to described species (cf. designation). Two of the taxa were new to science and were described in this manuscript.

\section{Taxonomic Section}

\section{Chlorophyta}

\section{Palmellopsis californica Flechtner et Johansen sp. nov. (Fig. 2)}

Colonia acervata, compacta, subviridis. Cellulae in muco inclusae, cellulis solitaribus a muco homogeneo circumcinctis, sphericae vel ovoideae, pariete cellulae incrassato, 8-16 $\mu \mathrm{m}$ diametro. Chloroplastus parietalis, limitatus ad latum unicum, integer vel cum rima, pyrenoide in medio in vagina incrassato amyli incluso. Guttae olei in cytoplasmate granulari visibiles. Zoosporae parietibus firmis, ellipsoideae, stigmate parvo, vacuola contractili antico, nucleo postico, 3.5-4 $\mu \mathrm{m}$ latae, 7-9 $\mu \mathrm{m}$ longae.

Holotypus hic designatus: figura nostra 2.

Colony mounded, compact, light green. Cells embedded in common mucilage, with individual cells surrounded by unlayered mucilage, spherical to ovoid, with thickened cell wall, $8-16 \mu \mathrm{m}$ in diameter. Chloroplast parietal, hugging 1 side, entire or slit with single median pyrenoid enclosed in a thick starch sheath. Oil droplets visible in granular cytoplasm. Zoospores walled, ellipsoidal, with small stigma, anterior contractile vacuole, posterior nucleus, 3.5-4 $\mu \mathrm{m}$ wide, 7-9 $\mu \mathrm{m}$ long.

Holotype here designated: our Fig. 2.

The genus Palmellopsis was split out from Palmella because the latter forms naked rather 
TABLE 3. Distribution of cyanobacteria in 7 sites on San Nicolas Island, CA. Site $1=$ hillside slope (CAS 1 ), site $2=$ hillside slope (CAS 2), site $3=$ hillside slope (CAS 3), site $4=$ island center (CATS 1), site $5=$ island center (CATS 2), site $6=$ island center $($ CATS 3$)$, site $7=$ island center $($ CATS 4$)$.

\begin{tabular}{|c|c|c|c|c|c|c|c|}
\hline \multirow[b]{2}{*}{ Taxon } & \multicolumn{7}{|c|}{ Sites } \\
\hline & 1 & 2 & 3 & 4 & 5 & 6 & 7 \\
\hline $\begin{array}{l}\text { SUBCLASS SYNECHOCOCCINEAE } \\
\text { Aphanocapsa fusco-lutea Hansg. } \\
\text { Leibleinia edaphica sp. nov. } \\
\text { Leptolyngbya cf. crispata (Playfair) Anag. et Kom. } \\
\text { Leptolyngbya cf. foveolarum (Rabh. ex Gom.) Anag. et Kom. } \\
\text { Leptolyngbya nostocorum (Born. ex Gom.) Anag. et Kom. } \\
\text { Leptolyngbya sp. } 3 \\
\text { Leptolyngbya sp. } 4 \\
\text { Leptolyngbya sp. } 5 \\
\text { Trichocoleus } \text { cf. delicatulus (West et. G.S. West) Anag. } \\
\text { Synechocystis pevalekii Ercegović }\end{array}$ & + & $\begin{array}{l}+ \\
+\end{array}$ & $\begin{array}{l}+ \\
+ \\
+\end{array}$ & $\begin{array}{l}+ \\
+\end{array}$ & & + & \\
\hline $\begin{array}{l}\text { SUBCLASS OSCILLATORIINEAE } \\
\text { Aphanothece maritima } \text { sp. nov } \\
\text { Chroococcidiopsis edaphica sp. nov. } \\
\text { Chroococcus cohaerens (Brébisson) Näg. } \\
\text { Cyanosarcina atroveneta sp. nov. } \\
\text { Gloeocapsa biformis Ercegović } \\
\text { Gloeocapsa compacta Kütz. } \\
\text { Plectonema } \text { cf. tomasinianum var. gracile Hansg. } \\
\text { Microcoleus vaginatus Gom. }\end{array}$ & $\begin{array}{l}+ \\
+ \\
+ \\
+ \\
+\end{array}$ & $\begin{array}{l}+ \\
+\end{array}$ & + & + & $\begin{array}{c} \\
\\
+ \\
+ \\
+\end{array}$ & + & + \\
\hline $\begin{array}{l}\text { SUBCLASS NOSTOCINEAE } \\
\text { Chlorogloeopsis fritschii (Mitra) Mitra et Pandey } \\
\text { Hassallia californica sp. nov. } \\
\text { Hassallia pseudoramosissima sp. nov. } \\
\text { Microcheate terrestre sp. nov. } \\
\text { Nostoc cf. borneti Gain } \\
\text { Nostoc desertorum Řeháková et Johan. } \\
\text { Nostoc paludosum Kütz. ex Born. et Flah. } \\
\text { Nostoc punctiforme (Kütz.) Hariot } \\
\text { Nostoc sphaericum Vauch. ex Born. et Flah. } \\
\text { Trichormus variabilis (Kütz. ex Born. et Flah.) Kom. et Anag. } \\
\text { Scytonema obscurum var. terrestre Hansg. } \\
\text { Scytonema ocellatum Lyngb. } \\
\text { Tolypothrix distorta var. symplocoides Hansg. } \\
\text { Tolypothrix cf. rupestris Wolle }\end{array}$ & $\begin{array}{l}+ \\
+\end{array}$ & $\begin{array}{l}+ \\
+ \\
+ \\
+ \\
+\end{array}$ & $\begin{array}{l}+ \\
+ \\
+\end{array}$ & + & $\begin{array}{l}+ \\
+\end{array}$ & $\begin{array}{l}+ \\
+ \\
+\end{array}$ & + \\
\hline
\end{tabular}

than walled zoospores. It differs from the genus Chlamydocapsa by having uniform rather than layered mucilage around individual cells. Two terrestrial species of Palmellopsis have been described. Our isolate differs from $P$. muralis Bold et King by lacking tetrahedral groups. It differs from $P$. texensis (Groover et Bold) Ettl et Gärtner on the basis of zoospore size. Our isolate forms zoospores that are 3.5$4 \mu \mathrm{m}$ wide and 7-9 $\mu \mathrm{m}$ long, while zoospores of P. texensis are 5.5-7.5 $\mu \mathrm{m}$ wide and 7.5-12.5 $\mu \mathrm{m}$ long.

\section{Pseudotetracystis compactis Flechtner et Johansen sp. nov. (Figs. 3-4)}

Colonia parva, acervata, fasciculis cellularum in muco inclusis, viridis in culturis juvenioribus, maturitate rubescens. Cellulae vegetativae in massa compacta crescentes, paribus et tetratibus visibilibus, generationibus paucis intra parietem unum saepe evidentibus, virides ubi juvenes, maturitate aurantiescens, adpressae lateribus contiguis complanatis ubi in fasciculis, non nisi ad $8 \mu \mathrm{m}$ latae et $6 \mu \mathrm{m}$ longae ubi in fasciculis, 6-16 $\mu \mathrm{m}$ diametro ubi solitariae. Chloroplastus parietalis. Pyrenoides una vel duae, vagina granuli amyli. Reproductio per desmoschisem, eleutheroschisem, vel productionem zoosporarum nudarum. Zoosporae quaternae in sporangio, lacriformes, stigmate parvo in medio vel antico. 3.2-4 $\mu \mathrm{m}$ latae, $6-8$ um longae.

Holotypus hic designatus: figura nostra 3.

Colony small, mounded, rough; with packets of cells imbedded in mucilage, bright green in 
TABLE 4. Distribution of eukaryotic algae in 7 sites on San Nicolas Island, CA. Site $1=$ hillside slope (CAS 1); site 2 $=$ hillside slope (CAS 2), site $3=$ hillside slope (CAS 3), site $4=$ island center (CATS 1), site $5=$ island center (CATS 2), site $6=$ island center (CATS 3), site $7=$ island center (CATS 4 ).

\begin{tabular}{|c|c|c|c|c|c|c|c|}
\hline \multirow[b]{2}{*}{ Taxon } & \multicolumn{7}{|c|}{ Sites } \\
\hline & 1 & 2 & 3 & 4 & 5 & 6 & 7 \\
\hline \multicolumn{8}{|l|}{ CHLOROPHYTA } \\
\hline Bracteacoccus sp. & + & + & + & & & + & + \\
\hline Chlorella mirabilis Andr. & & & & + & & & \\
\hline Chlorella vulgaris Beij. & & & + & & + & & \\
\hline Coccobotrys verrucariae Chod. & + & & & & & & \\
\hline Diplosphaera cf. chodatii Bialosuk. em. Vischer & + & + & + & + & + & + & + \\
\hline Klebsormidium flaccidum (Kütz.) Silva, Matt. \& Blackw. & & + & & & & & \\
\hline Myrmecia astigmatica Vinatzer & & & & & & + & + \\
\hline Myrmecia biatorellae (Tscher-Woess \& Plessl) Peters. & + & + & + & & + & + & \\
\hline Palmellopsis californicus sp. nov. & + & + & & & & + & \\
\hline Pseudotetracystis compactis sp. nov. & + & & & + & & + & + \\
\hline Scenedesmus deserticola Flechtner \& Lewis & + & + & & & & + & \\
\hline Spongiochloris minor Chantan. \& Bold & & & & & + & & + \\
\hline Stichococcus chlorelloides Grintzesco \& Péterfi & + & + & & & & & \\
\hline Trebouxia cf. aggregata (Archibald) Gärtner & + & & + & & & & \\
\hline \multicolumn{8}{|l|}{ EUSTIGMATOPHYTA } \\
\hline Eustigmatos magnus (Peters.) Hibberd & + & + & + & & & + & + \\
\hline \multicolumn{8}{|l|}{ TRIBOPHYTA } \\
\hline Heterococcus pleurococcoides Pitschm. & + & & & & & & + \\
\hline \multicolumn{8}{|l|}{ BACILLARIOPHYTA } \\
\hline Achnanthes coarctata (Bréb.) Grun. & + & & & & & + & \\
\hline Hantzschia abundans Lange-Bert. & & & + & + & & + & + \\
\hline Hantzschia amphioxys (Ehr.) Grun. & + & + & + & + & + & + & + \\
\hline Luticola cf. dismutica (Hust.) D.G. Mann & & & & & & + & + \\
\hline Luticola mutica (Kütz.) D.G. Mann & + & + & + & + & + & + & + \\
\hline Luticola nivalis (Ehr.) D.G. Mann & + & & & & & & \\
\hline Muelleria cf. gibbula (Cl.) Stoerm. et Spauld. & & & & & & + & \\
\hline Pinnularia sp. & & & & & & + & \\
\hline
\end{tabular}

young cultures, turning red with age. Vegetative cells growing in a compact mass, with diads and tetrads visible, with more than 1 generation often evident within 1 cell wall, green in young cells, becoming orange with age, appressed with adjacent sides flattened when in packets, only up to $8 \mu \mathrm{m}$ wide by 6 $\mu \mathrm{m}$ long when in packets, $6-16 \mu \mathrm{m}$ in diameter when solitary. Chloroplast parietal, with 1-2 pyrenoids. Pyrenoid with sheath of starch granules. Reproduction through desmoschisis, eleutheroschisis, or production of naked zoospores. Zoospores 4 per mother cell, with pointed anterior end, with rounded posterior end, with tiny median to anterior stigma, 3.2$4 \mu \mathrm{m}$ wide, $6-8 \mu \mathrm{m}$ long.

Holotype here designated: our Fig. 3.

The genus Pseudotetracystis was described in 1973 and up until this time was represented by only a single species, $P$. terrestris Arneson (1973). Watanabe (1983) described 2 additional strains from farm soils on Chichijima Island in the Pacific Ocean. Our isolate differs from the $P$. terrestris strain originally described by Arneson by having smaller vegetative cells and zoospores, having cells embedded in diffluent mucilage, and lacking a lobed chloroplast. Arneson (1973) reports sexual reproduction in his original isolate; we did not observe sexual reproduction. Pseudotetracystis compactis differs from the strains described by Watanabe in having smaller cells size and lacking autospore formation. A defining characteristic of our strain is the formation of large adherent cells masses rather than small groups of diads and tetrads.

\section{Klebsormidium flaccidum (Kütz.) Silva, Mattox et Blackwell (Fig. 5)}

Colony bright green, flat. Cells rectangular, forming a long filament; either not or slightly constricted at cross walls, 6-6.4 $\mu \mathrm{m}$ wide and 14-26 $\mu \mathrm{m}$ long. Chloroplast solitary, hugging 
the outside wall along the entire or partial length of the cell, with naked pyrenoid.

\section{Coccobotrys verrucariae Chodat em. Vischer (Figs. 6-7)}

Colony flat, without upright filaments. Cells spherical to oval, some irregular in shape, solitary or in filaments extending from a base of several cells, constricted at the cross walls, 6-10 $\mu \mathrm{m}$ in diameter. End cell sometimes elongated. Chloroplast parietal, trough-shaped, and highly lobed.

Diplosphaera cf. chodatii Bialosukniá em. Vischer (Figs. 8-10)

Lichen phycobiont. Colony initially olive green with dark debris on top, becoming yellow-green as algae are cultivated away from mycobiont. Cells in masses when originally isolated (Fig. 8), forming diads and tetrads when isolates become free from fungus (Figs. 9-10). Single cells spherical to ellipsoid, flattened along shared walls when growing in tetrads, olive when newly isolated, becoming lighter in color as cells pass through repeated transfers, 5-6 $\mu \mathrm{m}$ wide, 5-8 $\mu \mathrm{m}$ long. Chloroplast parietal, sometimes filling only part of the cell, with faint pyrenoid visible usually only after iodine staining.

We recovered numerous isolates of this Diplosphaera species. It fits $D$. chodatii fairly well, except that our taxon has a larger size range than that reported in the literature (3-4 $\mu \mathrm{m}$ wide, 4-7 $\mu \mathrm{m}$ long).

\section{Trebouxia incrustata Ahmadjian et Gärtner (Fig. 11)}

Cells spherical, 6-18 $\mu \mathrm{m}$ wide occurring singly or in groups. Chloroplast central, massive, with clearly lobed edge, with naked pyrenoid. Reproduction via autospores which can remain within the mother cell wall for a long period. Zoospores unobserved.

\section{Stichococcus chlorelloides Grintzesco et Péterfi (Fig. 12)}

Colony circular, flat, medium green. Cells barrel shaped, long with rounded ends, occurring singly or in pairs, 3-4 $\mu \mathrm{m}$ wide by $4-9 \mu \mathrm{m}$ long. Chloroplast parietal, pale green, covering a portion of the cell perimeter, lacking pyrenoid.

\section{Myrmecia astigmatica Vinatzer (Fig. 13)}

Lichen phycobiont. Colony adherent, containing bright green clumps of cells. Cells in a mass, spherical to ellipsoid or slightly irregular, 4-18 (24) um diameter. Cell wall not thickening with age. Chloroplast lobed, lacking pyrenoid. Nucleus single, slightly eccentric, with large nucleolus. Reproduction by autospores ( $>16$ per mother cell) and motile naked zoospores. Zoospores teardrop-shaped with pointed anterior and rounded posterior, with anterior contractile vacuole, with median nucleus, astigmate, 2.4-3 $\mu \mathrm{m}$ wide, $10 \mu \mathrm{m}$ long.

\section{Myrmecia biatorellae (Tschermak-Woess et Plessl) Peters. (Figs. 14-15)}

Colony adherent, dark green, rough. Cells typically in a irregular large mass or in small clusters radiating from a central point of attachment, spherical with single parietal chloroplast when young, 4-24 $\mu \mathrm{m}$ in diameter, developing a lobed chloroplast and becoming ellipsoidal with age, 4-24 $\mu \mathrm{m}$ wide, $13-30 \mu \mathrm{m}$ long. Reproduction via autospores ( $>16$ per mother cell) or motile zoospores. Zoospores naked, teardrop-shaped, with pointed anterior and rounded posterior, with anterior contractile vacuole and anterior nucleus, with posterior chloroplast, astigmate, $2.5-4 \mu \mathrm{m}$ wide, $5-10$ um long.

\section{Spongiochloris cf. minor Chantan. et Bold} (Figs. 16-18)

Colony mounded; orange-brown. Vegetative cells spherical; young cells without carotenoid pigment, 2-24 $\mu \mathrm{m}$ in diameter with thin cell wall. Older cells to $46 \mu \mathrm{m}$ with cell wall thickening to $1.6 \mu \mathrm{m}$. Chloroplast spongy, filling entire cell, with 1 to several large pyrenoids with 4 or more large starch grains, often excentric. Orange/red pigment accumulates in older cells, obscuring chloroplast. Zoospores unobserved.

\section{Bracteacoccus sp. (Figs. 23-24)}

Colony flat, medium green. Cells mostly spherical to ovoid, sometimes irregular in shape, with thin cell wall, 5-20 $\mu \mathrm{m}$ in diameter. Chloroplasts multiple, small, parietal, with some orange pigment production in old cells. Reproduction via autospores or naked zoospores 
(4 per sporangium). Zoospores containing 2 chloroplasts, with pointed anterior, with rounded posterior, astigmate, 2.4-3.2 $\mu \mathrm{m}$ wide by $6-8 \mu \mathrm{m}$ long.

This isolate does not fit any previously described species of Bracteacoccus. The astigmatic zoospore would suggest that the isolate belongs in the species Bracteacoccus minutus Schwartz, but the maximum cell size of this isolate is larger than that reported for B. minutus (20 $\mu \mathrm{m}$ compared to $14 \mu \mathrm{m}$ ), the size of the zoospores of this isolate differs from the size given for those of $B$. minutus $(2.4-3.2 \mu \mathrm{m}$ wide by $6-8 \mu \mathrm{m}$ long compared to $2 \mu \mathrm{m}$ wide by 8-12 $\mu \mathrm{m}$ long), and the chloroplasts of our isolate are smooth-edged rather than the angular disc shape described for B. minutus. The vegetative cell shape and size and the zoospore size are similar to those reported for Bracteacoccus pseudominor Bischoff et Bold, but the chloroplasts of this species are few in number and large, and the zoospores have a basal stigma. Given the absence of sequence data, we are reluctant to name this isolate as a new species.

\section{Scenedesmus deserticola Flechtner et Lewis (Fig. 25)}

Colony yellow green, spreading. Cells always solitary, spherical to oval, pointed on 1 or both ends, some cells developing filamentous extensions from 1 or both poles when cultivated in liquid medium, uninucleate, sometimes with accumulation of orange pigment, (3)-7-21 um wide, 8-24 um long. Chloroplast parietal, perforated, with 1 to several obvious circular or oblong pyrenoids covered with a starch sheath. Reproduction through 4 autospores per mother cell that remain in mother cell wall.

\section{TRIBOPHYTA}

\section{Heterococcus pleurococcoides Pitschm.}

(Fig. 22)

Colony with no upright filaments. Cells solitary, in tetrads, or in short filaments, spherical to oval, with multiple parietal chloroplasts, 5-12.5 um diameter.

Our specimens showed few cylindrical cells, and appeared very coccoid. The coccoid appearance is characteristic of this species (Ettl 1978). Our cells were slightly larger than listed for the taxon, although on $1 \%$ glucose agar, cells of similar size and plastid number have been seen (Ettl 1978).

\section{EUSTIGMATOPHYTA}

\section{Eustigmatos magnus (Peters.) Hibberd}

(Figs. 19-21)

Colony slightly mounded, dark to olive green, sometimes with orange pigment at edge. Cells spherical to ovoid, existing singly or in a mass. Young cells 6-20 $\mu \mathrm{m}$ in diameter, with lobed parietal chloroplast and crystalline body, with large vacuole in which Brownian movement is evident. Cell wall thin in young cells, thickening slightly as cells age. Older cells increase in size to $45 \mu \mathrm{m}$ in diameter, and chloroplast fragments. Red to orange pigment accumulates either as 1 large droplet or dispersed droplets. Small water-filled vacuoles often evident.

Reproduction through autospores, typically 4 per mother cell, or motile zoospores. Zoospores elongated, naked, sometimes swollen centrally, shortening quickly to become teardrop shaped, and rounding up soon after release, uniflagellate with a band-like chloroplast girdling the cell, 1 yellow anterior eyespot, an anterior to median nucleus, of variable size $(2.4-4 \mu \mathrm{m}$ diameter, $8-16 \mu \mathrm{m}$ in length), with up to 16 zoospores produced per mother cell.

Several authors report cell sizes (both vegetative and zoospore) smaller than those we observed. Generally, the maximum size for $E$. magnus is given as $34 \mu \mathrm{m}$ (Ettl 1978, Ettl and Gärtner 1995); although Hibberd (1981) states that the largest cells in culture can be up to 50 $\mu \mathrm{m}$ in diameter. Zoospores in our strain are more like those reported for Eustigmatos polyphem (Pitschm.) Hibberd, having both the central swelling and greater length characteristic of this species. Larger specimens in our cultures resembled the highly lobed chloroplast of E. polyphem as well (Ettl and Gärtner 1995). These 2 taxa have been combined in the past (Ettl 1978), and diagnosis of the species is complicated by the fact that in Ettl's original treatment he illustrates both taxa under the epithet Pleurochloris magna Peters. without referencing some of the drawings to $P$. polyphem (Ettl 1978). It seems possible that if both species are narrowly defined (Hibberd 
1981), our strains could represent a new species. If the taxa are more broadly delimited, then all 3 could be the same species. More work on this interesting and little-studied genus is needed.

\section{BACILLARIOPHYTA}

\section{Achnanthes coarctata (Bréb.)}

Grun. (Figs. 98, 99)

Valves $7 \mu \mathrm{m}$ wide, $24-28 \mu \mathrm{m}$ long, striae on raphe valve $17-18$ in $10 \mu \mathrm{m}$, striae on rapheless valve 15 in $10 \mu \mathrm{m}$.

\section{Hantzschia abundans Lange-Bert.}

(Figs. 105-108)

Valves 7-8 $\mu \mathrm{m}$ wide, 39-50 $\mu \mathrm{m}$ long, striae 17-20 in $10 \mu \mathrm{m}$. This species was separated recently from Hantzschia amphioxys. The key features are the larger size and much coarser striation, although the shape differs to some degree as well.

\section{Hantzschia amphioxys (Ehr.) Grun.}

(Figs. 102-104)

Valves 5-6 vm wide, 26-27 $\mu \mathrm{m}$ long, striae $24-25$ in $10 \mu \mathrm{m}$. This taxon is ubiquitous in biological soil crusts of the western United States.

\section{Luticola cf. dismutica (Hust.) D.G. Mann (Figs. 83-89)}

Valves 5-6 $4 \mathrm{~m}$ wide, 11-22 $\mu \mathrm{m}$ long, striae $16-18$ in $10 \mu \mathrm{m}$ in the center, $20-22$ in $10 \mu \mathrm{m}$ at the ends. Our populations bear closest resemblance to forms from Uruguay listed as Luticola sp. cf. dismutica (Plate 79, figs. 1-7, in Metzeltin et al. 2005). They also fit the illustrations in Hustedt (1961-1966). However, when one examines the type material for the species (Plate 760, figs. 12-16, in Simonsen 1987), it is clear that L. dismutica is different from our material. Our form also resembles Navicula lagerheimii var. intermedia Hustedt in Schmidt (1874-1959), published in 1930. However, by the time Hustedt illustrated the taxon in a flora (fig. 1593d, Hustedt 19611966), the nominate and the variety had been subsumed into Navicula mutica f. intermedia Hust.

\section{Luticola mutica (Kütz.) D.G. Mann}

(Figs. 76-82, 91-97)

Valves 5-7 $\mu \mathrm{m}$ wide, 9-21 $\mu \mathrm{m}$ long, striae $14-16$ in $10 \mu \mathrm{m}$ in the center, $18-20$ in $10 \mu \mathrm{m}$ at the ends. The coarsely striated specimens (Figs. 76-82) are typical representatives of this species. More finely striated forms (Figs. 91-97), with striae 16-18 in $10 \mu \mathrm{m}$ in the center and 18-22 in $10 \mu \mathrm{m}$ at the ends, may represent a different species, different deme, or simply the variation within populations. This question will likely not be solved without culturing and molecular sequence analysis.

\section{Luticola nivalis (Ehr.) D.G. Mann}

(Fig. 90)

Valves $5 \mu \mathrm{m}$ wide, $16 \mu \mathrm{m}$ long, striae 20 in $10 \mu \mathrm{m}$ in the center, 24 in $10 \mu \mathrm{m}$ at the ends. Our form is less pronounced in the extent of the undulations of the valve margins than most forms illustrated in the past (Hustedt 19611966).

\section{Muelleria cf. gibbula (Cl.) Stoerm. et Spauld. (Fig. 100)}

Valves $6 \mu \mathrm{m}$ wide, $26 \mu \mathrm{m}$ long, striae 23 in $10 \mu \mathrm{m}$. Our form is allied to M. gibbula, but is distinctly swollen in the central area. Only a single valve was observed.

\section{Pinnularia sp. (Fig. 101)}

Valves $4.3 \mu \mathrm{m}$ wide, $24 \mu \mathrm{m}$ long, striae 1920 in $10 \mu \mathrm{m}$. Despite an extensive search, we were not able to find any taxon close to this form.

\section{Cyanobacteria}

Synechococcineae

\section{Aphanocapsa fusco-lutea Hansg.}

(Fig. 26)

Colony mucilaginous, formless, diffluent, dirty yellow green, microscopic. Mucilage colorless, unlamellated, with individual sheaths not evident. Cells spherical, yellowish, sparsely distributed within the mucilage, $1.4-1.8 \mu \mathrm{m}$ in diameter. 
Our specimens fit this taxon fairly well, although our cells were a bit larger than previously reported.

\section{Synechocystis pevalekii Ercegović}

(Fig. 27)

Cells associated with mucilage of filamentous cyanobacteria, solitary or in pairs, spherical, after division hemispherical, clearly with cell division in 2 planes, with homogenous blue green contents, 2-3.4 $\mu \mathrm{m}$ in diameter.

\section{Leibleinia edaphica Johansen et Flechtner sp. nov. (Figs. 28, 66)}

Fila circum fila Tolypothrycis arcte volubilia, usque ad $3.5 \mu \mathrm{m}$ latae. Vagina incoloris, mollis. Trichomae ad septa leviter constrictae, necridiis absentibus, 2-3 $\mu \mathrm{m}$ latae. Cellulae chromoplasmate peripheralibus, aeruginosae, non granulares, isodiametricae ad leviter longiores quam latae, 2-3 $\mu \mathrm{m}$ longae. Cellulae apicales obtusirotundatae, non differentes a cellulis ceteris.

Holotypus hic designatus: figura nostra 28.

Filaments wound tightly around Tolypothrix filaments, up to $3.5 \mu \mathrm{m}$ wide. Sheath colorless, soft. Trichomes slightly constricted at the crosswalls, lacking necridia, 2-3 $\mu \mathrm{m}$ wide. Cells with peripheral chromoplasm, blue-green, nongranular, isodiametric to slightly longer than wide, 2-3 $\mu \mathrm{m}$ long. End cells bluntly rounded, not set off from other cells.

Holotype here designated: our Fig. 28.

Distinct from all other species in the genus by its terrestrial habitat, with filaments and trichomes larger than all described freshwater species.

\section{Leptolyngbya cf. crispata (Playfair) Anag. et Kom. (Fig. 29)}

Colonies blue green at first, developing purplish brown upper surface with age, flat and spreading. Filaments with single and double false branching, with only 1 trichome per sheath, 4-6 $\mu \mathrm{m}$ wide. Sheath soft, colorless. Trichomes not tapering, slightly constricted at the crosswalls, with necridia, 3-4 $\mu \mathrm{m}$ wide. Cells with thylakoids peripheral along the outside walls and crosswalls, 1-2 $\mu \mathrm{m}$ long. End cells hemispherical, bluntly rounded, up to 3 um long.
This form belongs to the group of species containing L. crispata and L. schmidlei (Liman) Anag. et Kom. It is wider than both of those taxa, and has a different habitat preference, but has the distinctive traits of very short cells and repeated false branching. We have seen populations similar to this one in the Sevilleta LTER in New Mexico (e.g., SEV5-3-c28 in fig. 2 in Johansen and Casamatta 2005). It belongs to the clade containing the soil forms of Leptolyngbya sensu stricto (Johansen et al. 2008).

\section{Leptolyngbya cf. foveolarum (Rabh. ex Gom.) Anag. et Kom. (Fig. 31)}

Colonies yellowish green with radiating filaments. Filaments flexuous, entangled, lacking false branching, with 1 trichome, $1.6 \mu \mathrm{m}$ wide. Sheath thin, colorless, evident. Trichomes slightly constricted at the crosswalls, with necridia, $1.6 \mu \mathrm{m}$ wide. Cells with thylakoids peripheral along the outside walls and the crosswalls, mostly shorter than wide, 1-1.6 $\mu \mathrm{m}$ long. End cells not set off from other cells in trichome.

Leptolyngbya foveolarum is presently one of the only truly edaphic forms in the subgenus Leptolyngbya (Komárek and Anagnostidis 2005). The shorter than wide to isodiametric cells with clear peripheral thylakoids along outside walls and crosswalls indicate that our form is in Leptolyngbya sensu stricto (Johansen et al. 2008). We seriously doubt our species is identical to the form described from European soils, and recognize that the L. foveolarum group needs study and revision.

\section{Leptolyngbya nostocorum (Born. ex Gom.)} Anagnostidis et Komárek (Fig. 30)

Colony is mucilaginous, raised, blue-green at first, apricot-colored in old culture. Filaments straight, flexuous, at times tightly spiraled, without false branching, 2.3-3.4 $\mu \mathrm{m}$ wide. Sheath thin, soft. Trichomes constricted at the crosswalls, without necridia, 1.6-2.2 $\mu \mathrm{m}$ wide. Cells with thylakoids peripheral along outside walls when visible, a few cells containing minute granules, longer than wide, 2-4-(6) um long. End cells rounded.

This species description was a very good fit for this soil species. The San Nicolas Islands are certainly more arid than the type locality, but we did not consider the ecological separation 
to be great enough to warrant description of our specimens as a separate taxon.

\section{Leptolyngbya sp. 3 (Fig. 32)}

Colonies olive with hormogonia evident at the margins. Filaments flexuous, entangled, lacking false branching, with 1 trichome, 2.4-4 um wide. Sheath thin, colorless. Trichomes slightly constricted at the crosswalls, with necridia, untapered, $2.4 \mu \mathrm{m}$ wide. Cells with thylakoids peripheral along the outside walls and the crosswalls, 1.6-2.7 $\mu \mathrm{m}$ long. End cells bluntly rounded, up to $3 \mu \mathrm{m}$ long.

This form is morphologically identical to Phormidium pristleyi Fritsch, which is an aquatic Antarctic species. The mode of cell division and thylakoid structure indicate that it must be a member of the Pseudanabaenales and is likely in Leptolyngbya sensu stricto (Johansen et al. 2008).

\section{Leptolyngbya sp. 4 (Figs. 33, 67)}

Colony mostly flat, gelatinous, with a few aerial filaments. Filaments intertwined, lacking false branching, with 1 trichome only, 1.5$2.5 \mu \mathrm{m}$ wide. Sheath extends beyond end of trichome, thin, open, colorless. Trichomes not constricted at the crosswalls, lacking necridia, 1.5-2 $\mu \mathrm{m}$ wide. Cells longer than wide, with thylakoids peripheral along the outside walls, with large sap vesicles forming near crosswalls in senescent cultures, 5.5-8 $\mu \mathrm{m}$ long. End cells tapering to slightly pointed, with distinct apical red granules. Numerous colonies were seen.

We have seen this taxon in numerous desert soils, but it is not yet described. It corresponds with a number of strains sequenced from Natural Bridges National Monument (e.g., NB2-c2 in fig. 2 in Johansen and Casamatta 2005). The distinct apical red granules are easily visible in most apical cells (Fig. 67). Its phylogenetic placement suggests that it may belong to an as-yet-undescribed genus within the Pseudanabaenaceae.

\section{Leptolyngbya sp. 5 (Fig. 34)}

Colony blue green to olive, with some upright filaments extending from a gelatinous mass. Sheath soft, thin, colorless. Filaments entangled, with rare single false branching, with false branches short, $3.2 \mu \mathrm{m}$. Trichomes not constricted to indistinctly constricted at the crosswalls, 3.2-4 $\mu \mathrm{m}$ wide. Cells isodiametric to $5.5 \mu \mathrm{m}$ long. End cells bluntly rounded to bluntly conical.

Thylakoids were not visible in this enigmatic taxon. The morphology seems consistent with Phormidium, but the trichomes are very narrow for placement in that genus. We are placing it provisionally in Leptolyngbya.

\section{Trichocoleus cf. delicatulus (W. et G.S. West) Anag. (Fig. 35)}

Colony olive, with spreading, ropy fascicles of filaments. Filaments with 1 to several trichomes, without false branching, 2.4-10-(40) $\mu \mathrm{m}$ wide. Sheath thin, colorless, becoming diffluent. Trichomes flexuous, constricted at the crosswalls, lacking necridia, 1.2-1.6 $\mu \mathrm{m}$ wide. Cells with thylakoids peripheral along the outside walls, (1.6)-3-5 um long. End cells rounded to conical.

This taxon keys to T. delicatulus, but our strains had conical end cells. The cell dimensions, conical end cells, and sheath characteristics fit Schizothrix arenaria Gomont, but no false branching of filaments was observed.

\section{Oscillatoriineae}

\section{Aphanothece maritima Johansen et Flechtner} sp. nov. (Figs. 36, 68)

Coloniae minutae, sphericae, atrovirentes, usque ad $220 \mu \mathrm{m}$ diametro. Vagina incoloris, non lamellosa, strato firmo externo, vaginis individuis nullis. Cellulae sphericae vel ovoideae, dense dispositae, solitariae vel binatae, aeruginosae, non granulares, 4-5 $\mu \mathrm{m}$ latae ubi sphericae, usque ad 5-6 $\mu \mathrm{m}$ latae et 8-9 $\mu \mathrm{m}$ longae ubi maturae.

Holotypus hic designatus: figura nostra 36.

Colonies minute, spherical, dark green, up to $220 \mu \mathrm{m}$ wide. Sheath colorless, unlamellated, with a firm outer layer, with no individual sheaths. Cells spherical to oval, densely packed, singly or pairs, deep blue green, nongranular, 4-5 $\mu \mathrm{m}$ wide when spherical, up to $5-6 \mu \mathrm{m}$ broad and 8-9 $\mu \mathrm{m}$ long when mature.

Holotype here designated: our Fig. 36.

This species belongs in the subgenus Cyanogastrum, which in the past has been nearly restricted to the tropics (Komárek and Anagnostidis 1998). It is clearly separate morphologically 
and ecologically from all other taxa in the subgenus.

\section{Chroococcidiopsis edaphica Johansen et Flechtner sp. nov. (Figs. 37, 69)}

Coloniae sphericae, baeocystis confertim dispositis 4-32-(64), cellulis solitariis liberatis ubi maturis, usque ad $30 \mu \mathrm{m}$ latae. Cellulae sphericae, isodiametrice compressae vel ovoideae, chromoplasmate peripherali, 5.5-6 $\mu \mathrm{m}$ latae, 5.5-8 $\mu \mathrm{m}$ longae.

Holotypus hic designatus: figura nostra 37.

Colonies spherical, with 4-32-(64) compactly arranged baeocytes, breaking open to release individual cells, up to $30 \mu \mathrm{m}$ broad. Cells spherical, compressed isodiametric, or oval, with peripheral chromatoplasm, 5.5-6 $\mu \mathrm{m}$ wide, 5.5-8 um long.

Holotype here designated: our Fig. 37.

This taxon is most similar to Chroococcidiopsis kashayii Friedmann, differing from that taxon in the size of the cells and habitat preference.

\section{Chroococcus cohaerens (Brébisson) Näg. (Fig. 38)}

Colony an aggregation of small subcolonies. Sheath colorless, unlamellated. Cells nongranular, in tight subcolonies of 1-4 cells, blue green to olive, $2-3.4 \mu \mathrm{m}$ in diameter.

\section{Cyanosarcina atroveneta Johansen et Flechtner sp. nov. (Figs. 39, 70)}

Coloniae microscopicae, subcolonis numerosis in agglomeratione arcto. Vagina incoloris, difluens, tenuis. Cellulae profunde atrovenetae, sphaericae, in fasciculis cubicis densis cellularum octonorum ad sedinorum, fasciculis amplitudo magniore irregularescens, 1.8-2.1 um diametro.

Holotypus hic designatus: figura nostra 39.

Colonies microscopic, with numerous subcolonies in a tight agglomeration. Sheath colorless, diffluent, thin. Cells deep blackish bluegreen, spherical, in dense cubical packets of 8-16 cells, packets becoming irregular with greater size, 1.8-2.1 $\mu \mathrm{m}$ in diameter.

Holotype here designated: our Fig. 39.

This taxon is distinguished from all other Cyanosarcina species based on its dark blackish blue green coloration, and is additionally distinct because of its occurrence in semiarid soils. Cyanosarcina species were seen previously in moist soils only.

\section{Gloeocapsa biformis Ercegović (Figs. 40, 71)}

Colony microscopic, amorphous, yellow brown, with distinct subcolonies of 1-4 cells. Sheath yellow brown, not lamellated. Cells spherical to slightly oblong, pale blue green, $1.6-2.6 \mu \mathrm{m}$ in diameter.

Our specimens are a good fit morphologically. The original material was reported from chasmoendolithic habitats and calcareous rocks, which have some ecological overlap with desert soils.

\section{Gloeocapsa compacta Kütz. (Fig. 41-43)}

Colony amorphous, consisting of small subcolonies in a common matrix. Sheaths around cells colorless to bluish black, forming spheres 2.5-5 $\mu \mathrm{m}$ in diameter. Cells 1-2 together in a common sheath, blue green, nongranular, 1.4$2.4 \mu \mathrm{m}$ in diameter.

\section{Microcoleus vaginatus Gom. (Fig. 46)}

Colony consisting of rope-like filaments extending out from the center. Filaments with multiple trichomes per sheath, and with individual sheaths on single trichomes. Trichomes straight or tapering slightly at the apices, unconstricted at the crosswalls, which are granular, (5)-6-7 $\mu \mathrm{m}$ wide. Cells mostly longer than wide, with successive cell division, 2-7 $\mu \mathrm{m}$ long between complete septa. End cells with calyptra.

\section{Plectonema cf. tomasinianum var. gracile Hansg. (Figs. 44, 45)}

Colony filamentous, with some upright branches. Sheath colorless, unlamellated, varying unevenly in width, becoming yellow brown with age. Filaments intertwined, sometimes distinctly bent and curved, with both single and double false branching, up tol6 $\mu \mathrm{m}$ wide. Trichomes constricted at the crosswalls, with evident yellowish necridia, up to 10-14 $\mu \mathrm{m}$ wide. Cells 2.4-6 um long.

This isolate was a good fit morphologically, but the ecology was very wrong. This taxon was described from streams in the Czech Republic. 
Nostocineae

\section{Chlorogloeopsis fritschii (Mitra) Mitra et Pandey (Figs. 55, 72)}

Colony on agar dark olive green, small and rough, on reculture bright blue-green, in a mound in the center with numerous hormogonia spreading from the colony center. Subcolonies mostly pseudofilamentous, with some oblong or even spherical, generally consisting of filaments 1-2-(4) cells thick, becoming over 1000 um long. Cells of the filaments and other subcolonies densely packed, 4-10 $\mu \mathrm{m}$ wide, 4-6 $\mu \mathrm{m}$ long, dividing in 2 planes. Cells of hormogonia 3.2-4 $\mu \mathrm{m}$ in diameter, mostly shorter than wide, 2.8-5 um long. Heterocytes hemispherical, at the ends of small, elongated colonies, 4-5 $\mu \mathrm{m}$ wide.

\section{Hassallia californica Johansen et Flechtner sp. nov. (Figs. 59, 60, 73)}

Coloniae byssoideae, macroscopicae, asprae, implicitae, umbrinae. Fila saepe singulatim pseudoramosa, ramis axi principali seape fere perpendicularibus, in fila breviora facile rumpentia, 14-16 um lata. Vagina firma, non lamellata, incoloris in culturis impigre cresentibus. Trichomae ad septa distincte constictae, 11-12 $\mu \mathrm{m}$ latae. Cellulae obscure aeruginosae vel fuscoolivaceae, longitudine latidunine 4-7-plo breviore, 1.6-3.2 $\mu \mathrm{m}$ longae. Heterocyteae ovoideae, intercalariter primum crescentes, solitariae vel binatae, ad apicem filarum effactarum evidentissimae.

Holotypus hic designatus: figura nostra 59.

Colonies bushy, large, rough, matted, dark brown. Filaments frequently singly pseudobranched, with branches often nearly perpendicular to the main axis, fragmenting easily into very short filaments, 14-16 $\mu \mathrm{m}$ wide. Sheath firm, unlamellated, colorless in actively growing cultures. Trichomes distinctly constricted at the crosswalls, 11-12 um wide. Cells dull blue-green to dark olive, one-seventh to one-fourth as long as broad, 1.6-3.2 $\mu \mathrm{m}$ long. Heterocytes oval, first developing intercalary, single or paired, most evident at end of broken filaments.

Holotype here designated: our Fig. 59.

Most similar to H. byssoidea Hass. ex Born. et Flah., from which it differs by having much shorter cells and different habitat preference.
Also similar to Hassallia granulata Gardner, from which it differs by lacking the granulation at the crosswalls, much more repeated branching, and habitat preference.

\section{Hassallia pseudoramosissima Johansen et Flechtner sp. nov. (Figs. 57, 58, 74)}

Coloniae virides, byssoideae. Fila pseudoramosissima typice non ad heterocyteas, pseudoramificatione maximam partem singulare, pseudoramificatione duplici fila paralella affixa edenti, 11-20 $\mu \mathrm{m}$ lata. Vagina tenuis, incolorata, non lamellata. Trichomata constricta vel leviter constricta ad septa, necridiis frequentibus, 8-14 um lata. Cellulae venetae, breviores quam longiores, (2)-3-9 $\mu \mathrm{m}$ longae. Heterocyteae compressae rectangulares, 9-11 $\mu \mathrm{m}$ latae, 7-9 $\mu \mathrm{m}$ longae.

Holotypus hic designatus: figura nostra 58 .

Colony green, bushy. Filaments abundantly pseudobranched, typically not at the heterocytes, with most branching single, double false branching leads to attached parallel filaments as trichomes straighten after branching event, 11-20 $\mu \mathrm{m}$ wide. Sheath thin, colorless, unlamellated. Trichomes constricted to very slightly constricted at the crosswalls, with frequent necridia, 8-14 $\mu \mathrm{m}$ wide. Cells bright bluegreen, shorter than wide, (2)-3-9 $\mu \mathrm{m}$ long. Heterocytes compressed rectangular, 9-11 $\mu \mathrm{m}$ wide, 7-9 um long.

Holotype here designated: our Fig. 58.

This form is similar to $H$. byssoidea, but differs in the form and frequency of the branching. Our isolates are much more frequently false branched, with both single and double false branching. We had originally separated some of our isolates into $H$. byssoidea based upon color differences and relative sparseness of branching. However, in examining all material it became clear that transitional forms exist. Hassallia pseudoramosissima has wider trichomes and wider filaments than $H$. byssoidea. The degree of branching resembles H. bouteillei (Bréb. et Desm.) Born. et Flah.

\section{Microchaete terrestre Johansen et Flechtner sp. nov. (Figs. 56, 75)}

Coloniae trichomarum dispersarum supra agar constantes. Fila applanata, non pseudoramosa, heterocytea basali, (8)-13-22 um latae. Vagina lata, incoloris ochracescens, aspra, 
paucistrata, prope heterocytea basalem tenuior. Trichomae in parte basalem 12-14 $\mu \mathrm{m}$ latae, ad septa leviter constrictae, in parte apicalem 8-10 um latae, ad septa evidenter constrictae. Hormogonia brevia, abundantia, per fragmentationem simplicem sine necridiis formantia. Cellulae ubique granulares, 2-4 $\mu \mathrm{m}$ longae, ad basem usque ad $7 \mu \mathrm{m}$ longae. Heterocytea hemisphaerica, straminea, terminalis, $11 \mu \mathrm{m}$ lata, $8 \mu \mathrm{m}$ longa.

Holotypus hic designatus: figura nostra 56.

Colonies consisting of scattered trichomes on the agar. Filaments not upright, not false branched, with a basal heterocyte, (8)-13-22 $\mu \mathrm{m}$ wide. Sheath wide, colorless becoming golden, rough, layered, thinner near the basal heterocyte than in upper parts of trichome. Trichomes only slightly constricted at the crosswalls in the basal part of the trichome, which is $12-14 \mu \mathrm{m}$ wide, distinctly constricted at the crosswalls in the apical parts of the trichome, which are only 8-10 $\mu \mathrm{m}$ wide. Hormogonia short, abundant, arising from simple fragmentation without necridia. Cells granular, but not granular at the crosswalls, 2-4 $\mu \mathrm{m}$ long, up to $7 \mu \mathrm{m}$ long at the base. Heterocyte hemispherical, yellowish, terminal, $11 \mu \mathrm{m}$ wide, 8 um long.

Holotype here designated: our Fig. 56.

This isolate does not fit any taxa presently in the genus, and the semiarid terrestrial habitat is distinctive. The trichomes tapered from base to apex, but in no instance did the apical cells have diameters $<8 \mu \mathrm{m}$. Tapering is a feature reminiscent of Calothrix, but species in that genus taper to finer apices even in the taxa that do not taper to a hair.

\section{Nostoc cf. borneti Gain}

Colony mucilaginous, rounded. Trichomes widely dispersed in unstructured mucilage, with membrane apparent only at the periphery of the colony, 3.2-4.5 $\mu \mathrm{m}$ wide. Cells spherical to oval, 3-5.5 $\mu \mathrm{m}$ long. Akinetes 4 $\mu \mathrm{m}$ wide, $6 \mu \mathrm{m}$ long. Heterocytes spherical, 4 $\mu \mathrm{m}$ in diameter.

\section{Nostoc desertorum Řeháková et Johansen (Fig. 49)}

Colonies with colorless mucilage that becomes yellow, rough, and compartmentalized.
Trichomes densely arranged in the mucilage, although the filamentous nature is usually evident, $5 \mu \mathrm{m}$ wide. Hormogonia generally short, similar in morphology to trichomes in the colony, but only $3 \mu \mathrm{m}$ wide. Cells ovoid to cylindrical, 2.3-7.0 $\mu \mathrm{m}$ wide.

This Nostoc has likely been confused with N. commune Vaucher ex Born. et Flah. in the past. We saw no macroscopic colonies characteristic of that taxon but did see the compartmentalized mucilage characteristic of $N$. desertorum (̌̌eháková et al. 2007).

\section{Nostoc paludosum Kütz. ex Born. et Flah. (Fig. 50)}

Colony obviously mucilaginous, consisting of olive-green spherical subcolonies in a flat mass on the agar. Sheath colorless to yellowish, without a firm outer layer. Trichomes loosely coiled in the mucilage, $3.2-3.5 \mu \mathrm{m}$ wide. Hormogonia straight, common. Cells barrel shaped, isodiametric or shorter than wide, 2.4$3.5 \mu \mathrm{m}$ long. Akinetes oval, apoheterocytic, in long series, longer than wide, 4-5 $\mu \mathrm{m}$ wide, 5-7.2 um long. Heterocytes isodiametric, yellowish, $4 \mu \mathrm{m}$ wide, $4-5 \mu \mathrm{m}$ long.

\section{Nostoc punctiforme (Kütz.) Hariot}

(Fig. 51)

Colonies microscopic, forming a granular agglomeration on agar, olive green to brown. Sheath colorless at first, becoming golden brown. Trichomes densely arranged in the colonies such that filamentous nature is not readily evident, $4-5 \mu \mathrm{m}$ in diameter. Cells spherical, 4-6 $\mu \mathrm{m}$ long. Heterocytes observed, but very sparse, $4-5 \mu \mathrm{m}$ in diameter, $4-5 \mu \mathrm{m}$ long.

Nostoc sphaericum Vauch. ex Born. et Flah. (Figs. 52, 53)

Colony olive to golden, microscopic, evidently mucilaginous. Filaments not intertwined, widely dispersed in soft colonial mucilage, with individual sheaths not evident to slightly visible. Trichomes short, curved, 4-5.5 $\mu \mathrm{m}$ wide. Vegetative cells blue-green, 3.2-6 $\mu \mathrm{m}$ long. Akinetes $6-7 \mu \mathrm{m}$ wide, $7 \mu \mathrm{m}$ long, only slightly granular. Heterocytes spherical, 6-8 $\mu \mathrm{m}$ in diameter. 


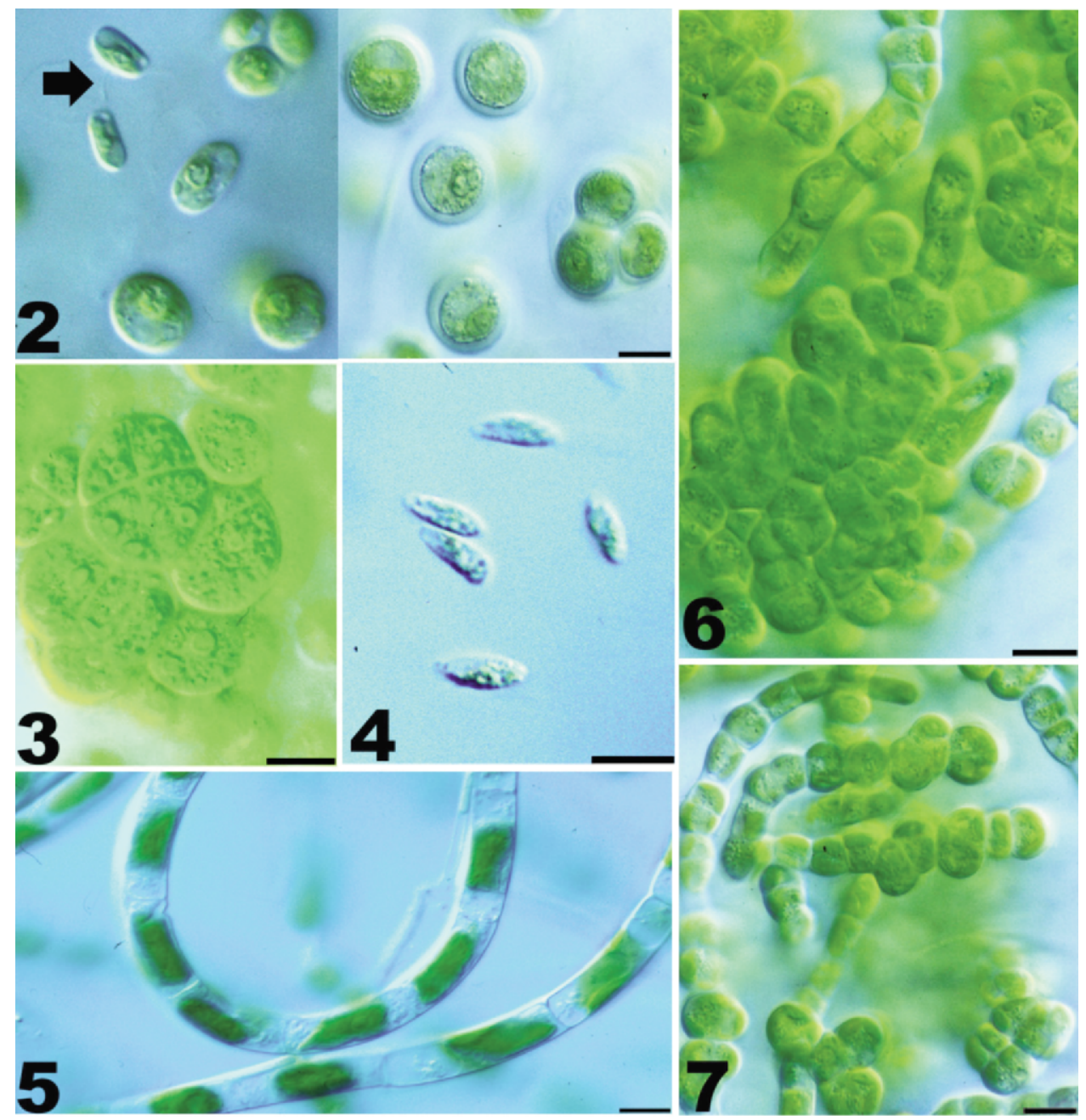

Figs. 2-7. Palmellopsis californica, Pseudotetracystis compactis, Klebsormidium flaccidum, and Coccobotrys verrucariae (scale bar $=10 \mu \mathrm{m})$. Fig. 2. P. californica, vegetative cells with individual sheaths and zoospores (indicated by arrow). Figs. 3-4. P. compactis: 3, packet formation in vegetative cells; 4, zoospores. Fig. 5. K. flaccidum. Figs. 6-7. C. verrucariae.

Scytonema obscurum var. terrestre Hansg. (Fig. 65)

Colonies of agar brown, tufted, with upright filaments. Filaments singly and doubly false branched, 11-13 $\mu \mathrm{m}$ wide. Sheath thin, colorless or gold. Trichomes unconstricted at the crosswalls, 10-11-(14) $\mu \mathrm{m}$ wide. Cells mostly shorter than wide, 4-6 $\mu \mathrm{m}$ long to isodiametric. Heterocytes intercalary, $12 \mu \mathrm{m}$ long, 6-12 $\mu \mathrm{m}$ wide.

This is a good morphological fit for this taxon, which was originally reported from wet soils. It is also similar to Scytonema tenellum Gardner, which was found on lava rocks and has wider trichomes and darker brown sheath material.

\section{Scytonema ocellatum Lyngb. (Fig. 64)}

Colonies olive to brown, flat, with filaments extending out beyond colony core, without upright filaments. Filaments singly and doubly pseudobranched, with single false branching a little more common, 8-14 $\mu$ m wide. Sheath thin or thickened with layers, lamellated, colorless to golden, to golden brown. Trichomes not or slightly constricted at the crosswalls, 6-8 $\mu \mathrm{m}$ wide. Cells light blue-green, granular or nongranular, mostly isodiametric or shorter 


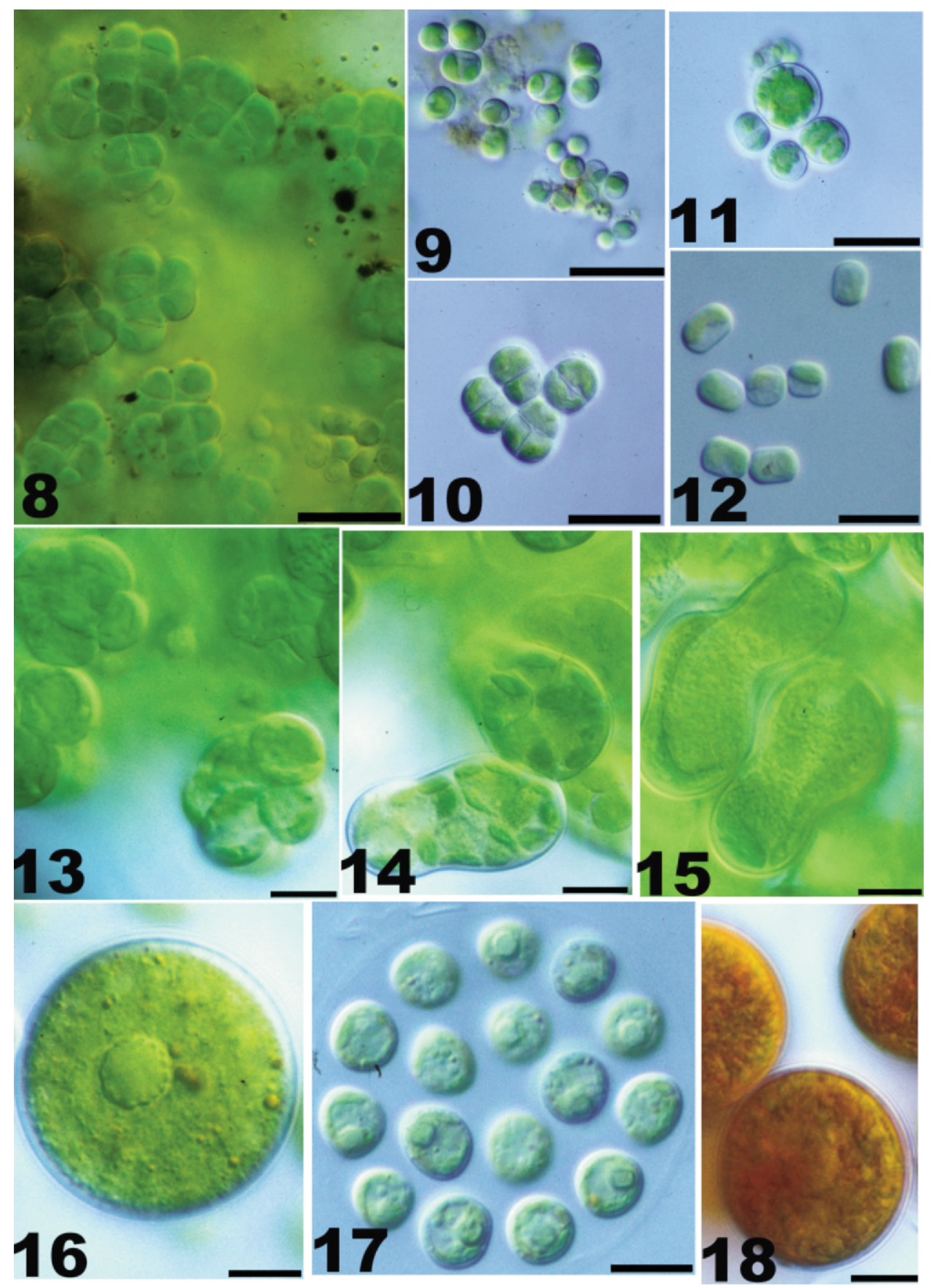

Figs. 8-18. Diplosphaera, Trebouxia, Stichococcus, Myrmecia, and Spongiochloris (scale bar = 10 um). Figs. 8-10. D. cf. chodatii: 8, cells freshly isolated from soil growing in packets and adhering in a mass (note dark debris on cell surface); 9, cells growing in subculture showing less adherence and more single cells; 10, dividing cells forming small groups. Fig. 11. T. incrustata, vegetative cells. Fig. 12. Stichococcus chlorelloides. Fig. 13. M. astigmatica, vegetative cells. Figs. 14-15. M. biatorellae: 14, sporangia producing autospores; 15, sac-like vegetative cells with lobed chloroplast. Figs. 16-18. Spongiochloris cf. minor: 16, vegetative cell during growth phase; 17, aplanospores still contained by sporangium; 18, carotenoid pigment accumulation in old cells. 


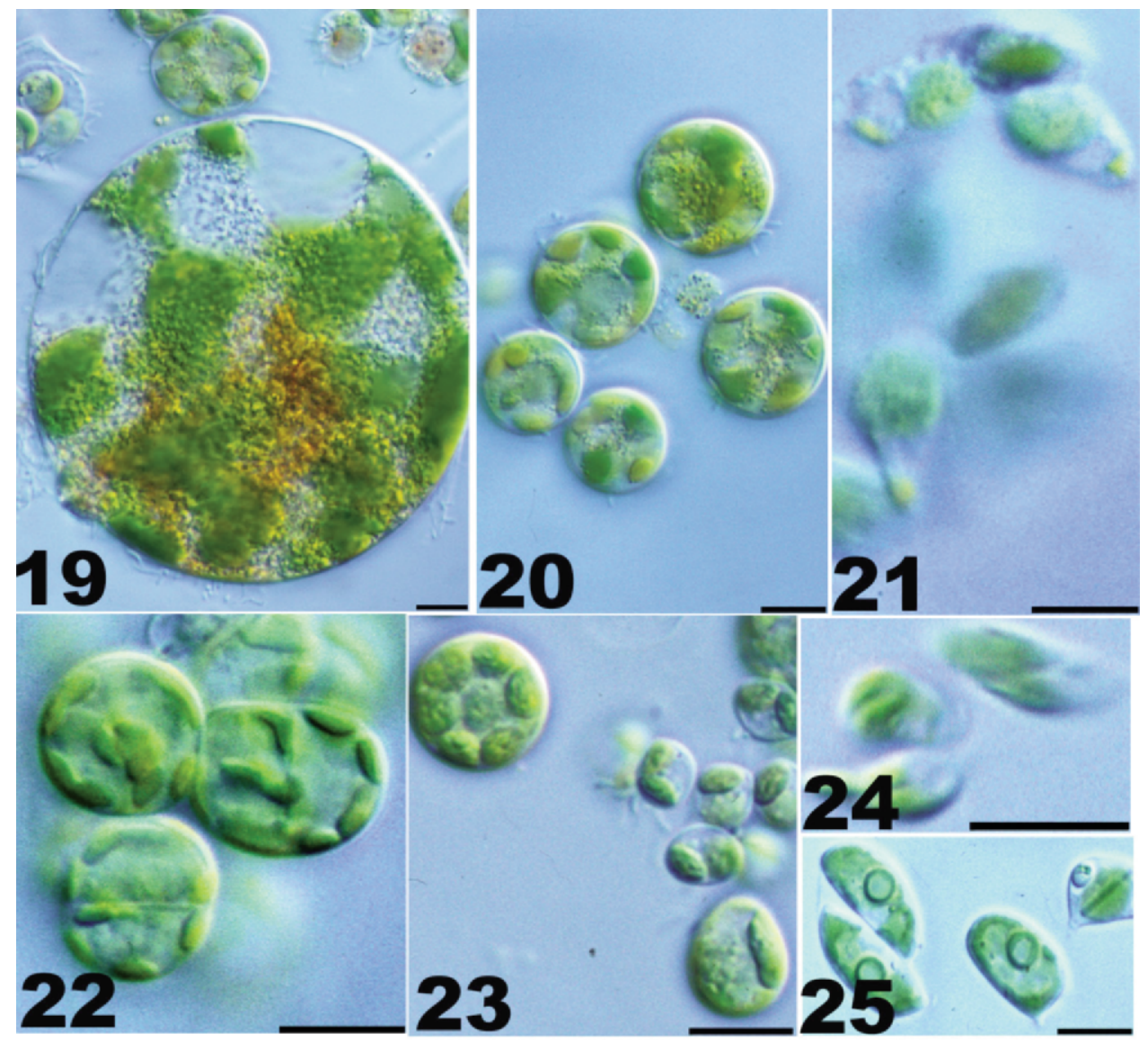

Figs. 19-25. Eustigmatos magnus, Heterococcus pleurococcoides, Bracteacoccus minor, and Scenedesmus deserticola (scale bar $=10 \mu \mathrm{m}$ ). Figs. 19-21. E. magnus: 19, mature vegetative cells showing pigment accumulation; 20, young vegetative cells showing lobed chloroplast and water-filled vacuole in which Brownian motion can be observed; 21 , zoospores. Fig. 22. H. pleurococcoides, cells with multiple chloroplasts. Figs. 23-24. Bracteacoccus sp.: 23, vegetative cells with multiple chloroplasts; 24 , zoospores. Fig. 25. S. deserticola, vegetative cells showing short filamentous extension developing on some cells in liquid.

than wide, in the main axis 3.5-8 $\mu \mathrm{m}$ long, reaching $14 \mu \mathrm{m}$ long in the recently formed branches. Heterocytes rectangular or compressed spherical, $9 \mu \mathrm{m}$ wide $\times 8 \mu \mathrm{m}$ long, 8 $\mu \mathrm{m}$ wide $\times 12 \mu \mathrm{m}$ long, $6 \mu \mathrm{m}$ wide $\times 10 \mu \mathrm{m}$ long.

\section{Tolypothrix distorta var. symplocoides Hansg. (Figs. 61, 62)}

Colonies green, becoming brown, bushy with upright bundles. Filaments singly false branched with long branches, 12-16-(23) $\mu \mathrm{m}$ wide. Sheath thin, firm, rough, colorless, becoming golden and layered with age. Trichomes unconstricted to slightly constricted at the crosswalls, 10-12-(16) $\mu \mathrm{m}$ wide. Cells bluegreen, sometimes with a single granule at the crosswall, sometimes with scattered granules in the cytoplasm, mostly shorter than wide, 4-10-(15) $\mu \mathrm{m}$ long. Heterocytes intercalary, sometimes in pairs, 8-12 $\mu \mathrm{m}$ wide, 4-12 $\mu \mathrm{m}$ long. End cell rounded, possibly with a cap.

Our taxon is a good morphological and ecological fit for this taxon, which was originally described from garden and greenhouse soils.

\section{Tolypothrix cf. rupestris Wolle (Fig. 63)}

Colonies diffuse, with scattered trichomes. Filaments long, not upright, twisted, with infrequent single false branching at the heterocytes, 8-15 $\mu \mathrm{m}$ wide. Sheath thin, unlamellated, 


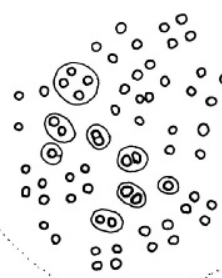

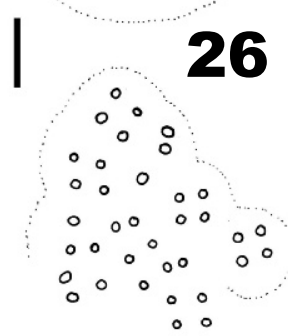

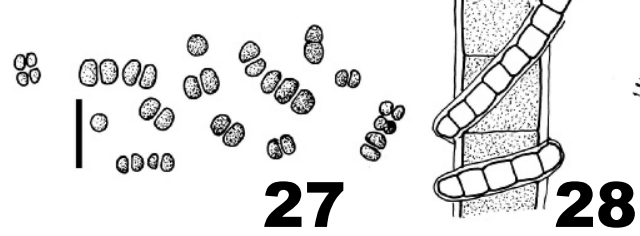
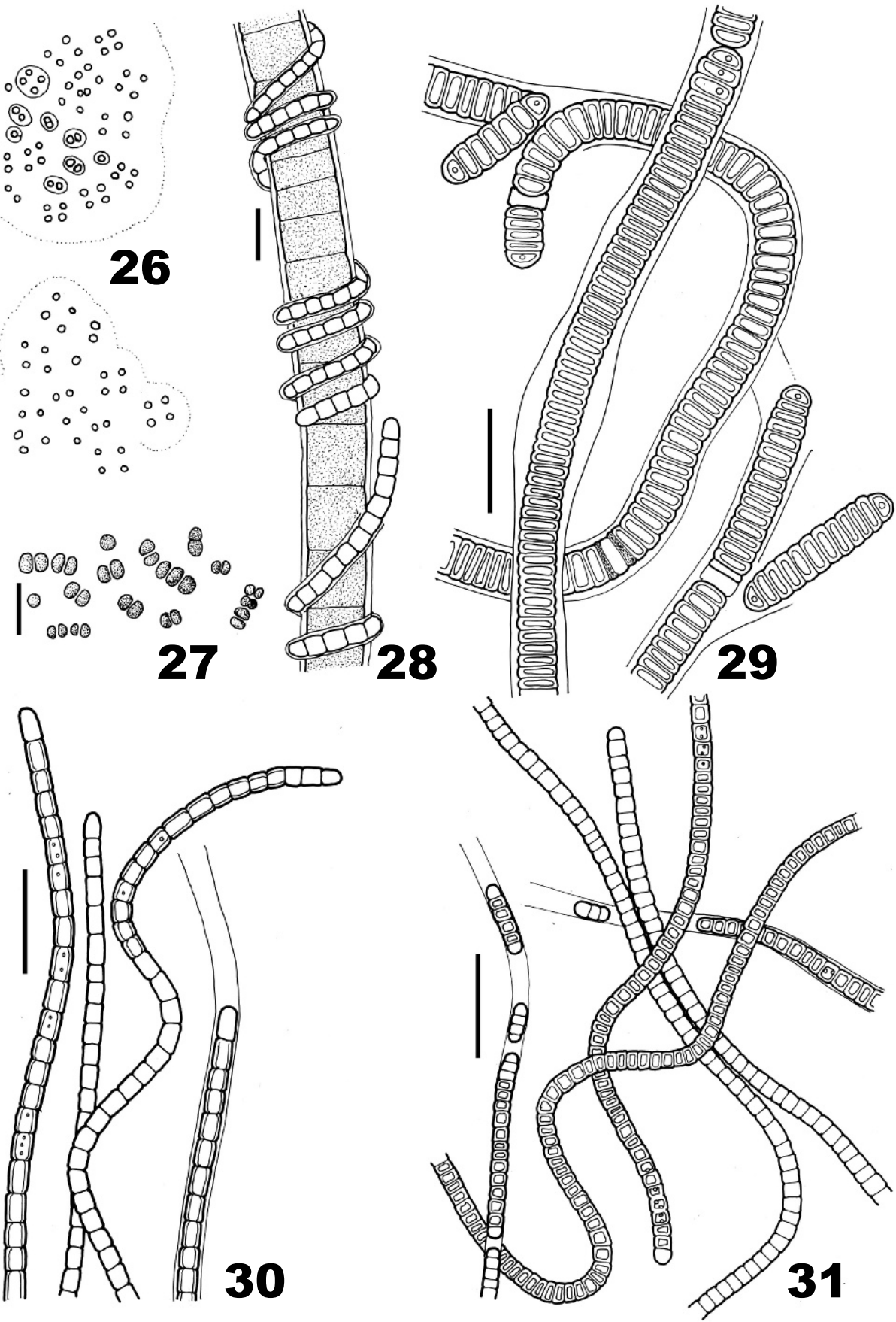

Figs. 26-31. Synechochoccineae (scale bar $=10 \mu \mathrm{m}$ ). Fig. 26. Aphanocapsa fusco-lutea. Fig. 27. Synechocystis pevalekii. Fig. 28. Leibleinia edaphica growing on Tolypothrix. Fig. 29. Leptolyngbya cf. crispata. Fig. 30. Leptolyngbya nostocorum. Fig. 31. Leptolyngbya cf. foveolarum. 

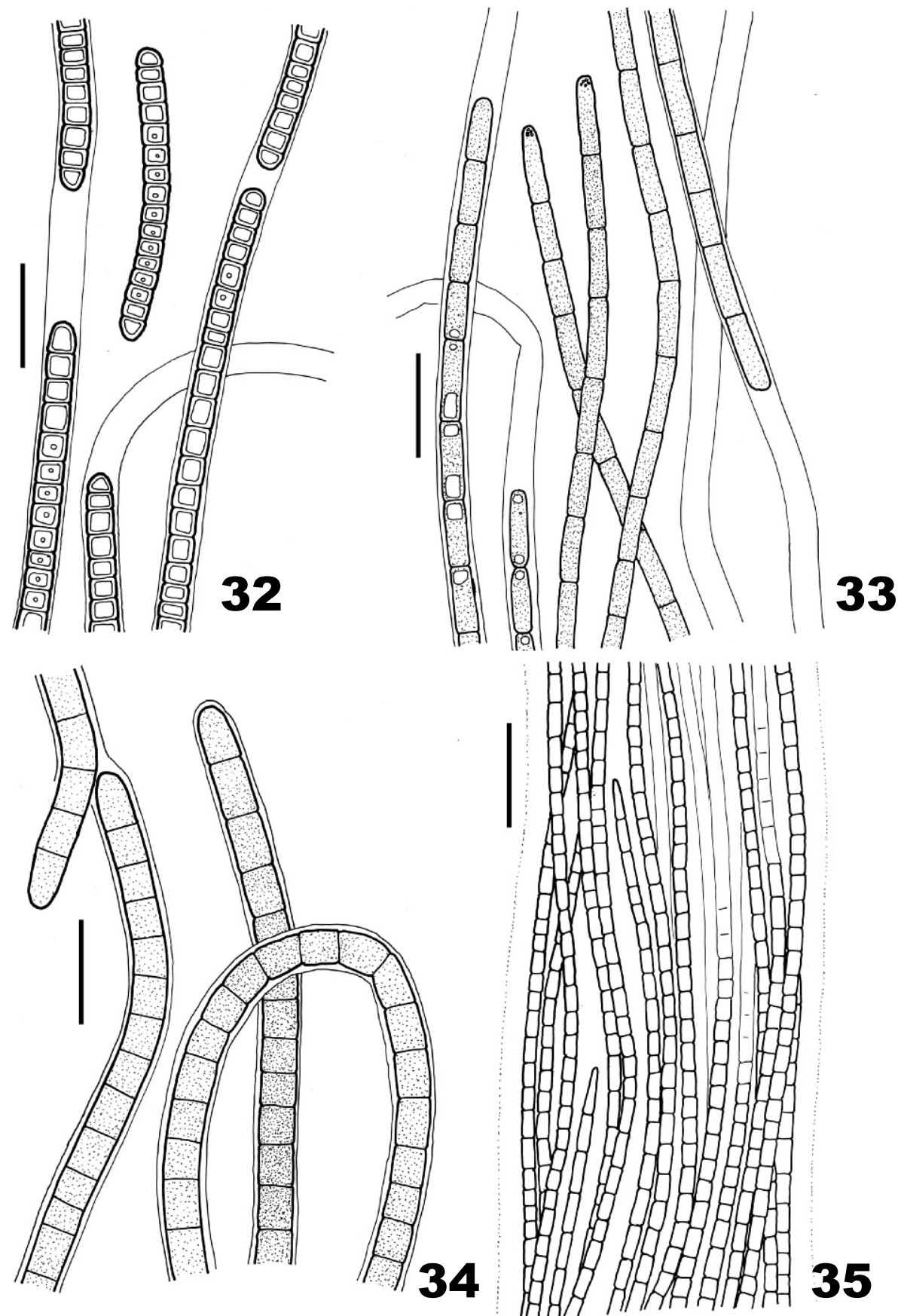

Figs. 32-35. Synechochoccineae (scale bar $=10 \mu \mathrm{m}$ ). Fig. 32. Leptolyngbya sp. 3. Fig. 33. Leptolyngbya sp. 4. Fig. 34. Leptolyngbya sp. 5. Fig. 35. Trichocoleus cf. delicatulus. 

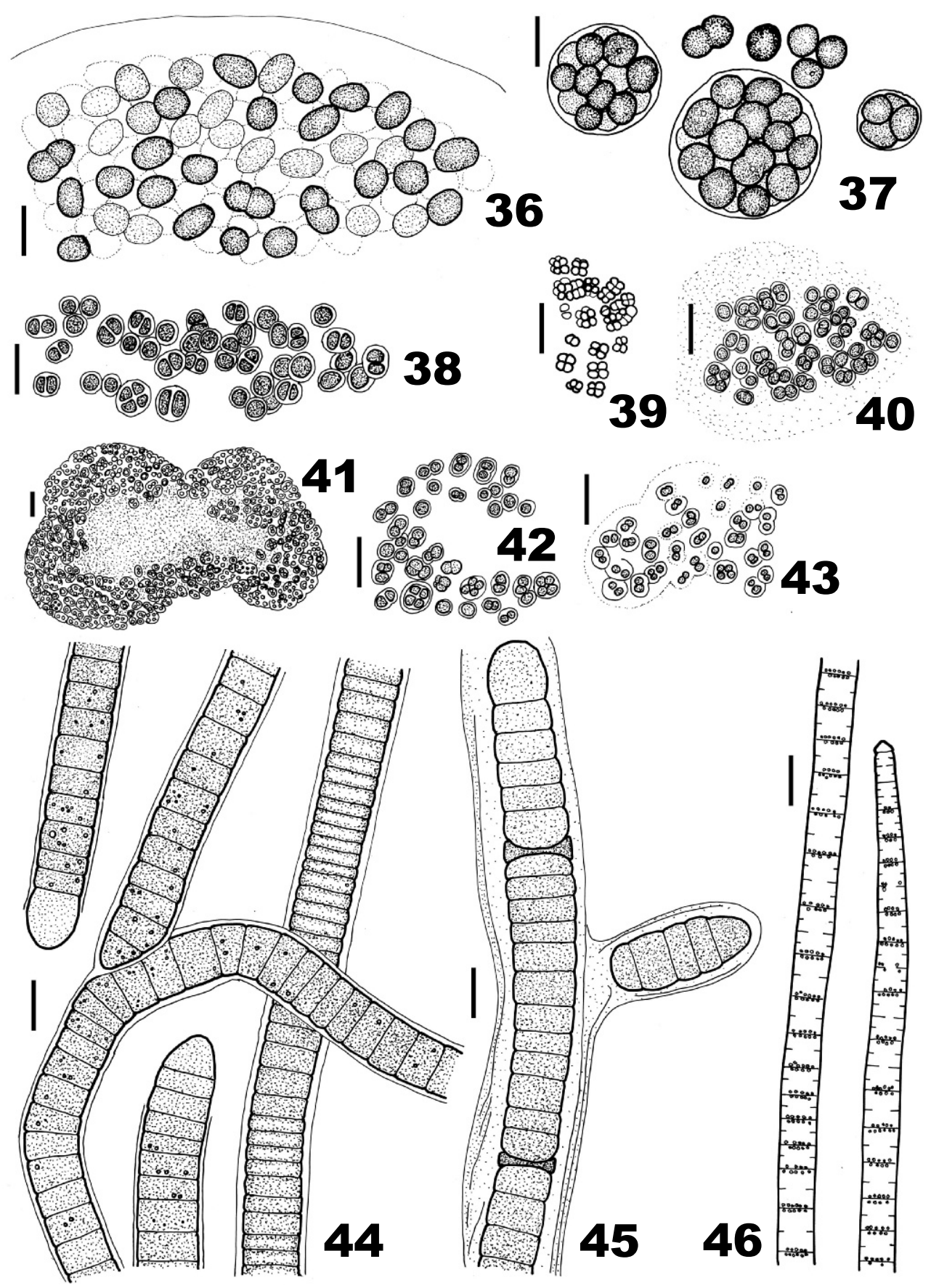

Figs. 36-46. Oscillatoriineae (scale bar $=10 \mu \mathrm{m}$ ). Fig. 36. Aphanothece maritima. Fig. 37. Chroococcidiopsis edaphica. Fig. 38. Chroococcus cohaerens. Fig. 39. Cyanosarcina atroveneta. Fig. 40. Gloeocapsa biformis. Figs. 41-43. Gloeocapsa compacta. Fig. 44. Plectonema cf. tomasinianum var. gracile, young culture with colorless sheaths. Fig. 45. Plectonema cf. tomasinianum var. gracile, old culture with yellow sheath. Fig. 46. Microcoleus vaginatus. 

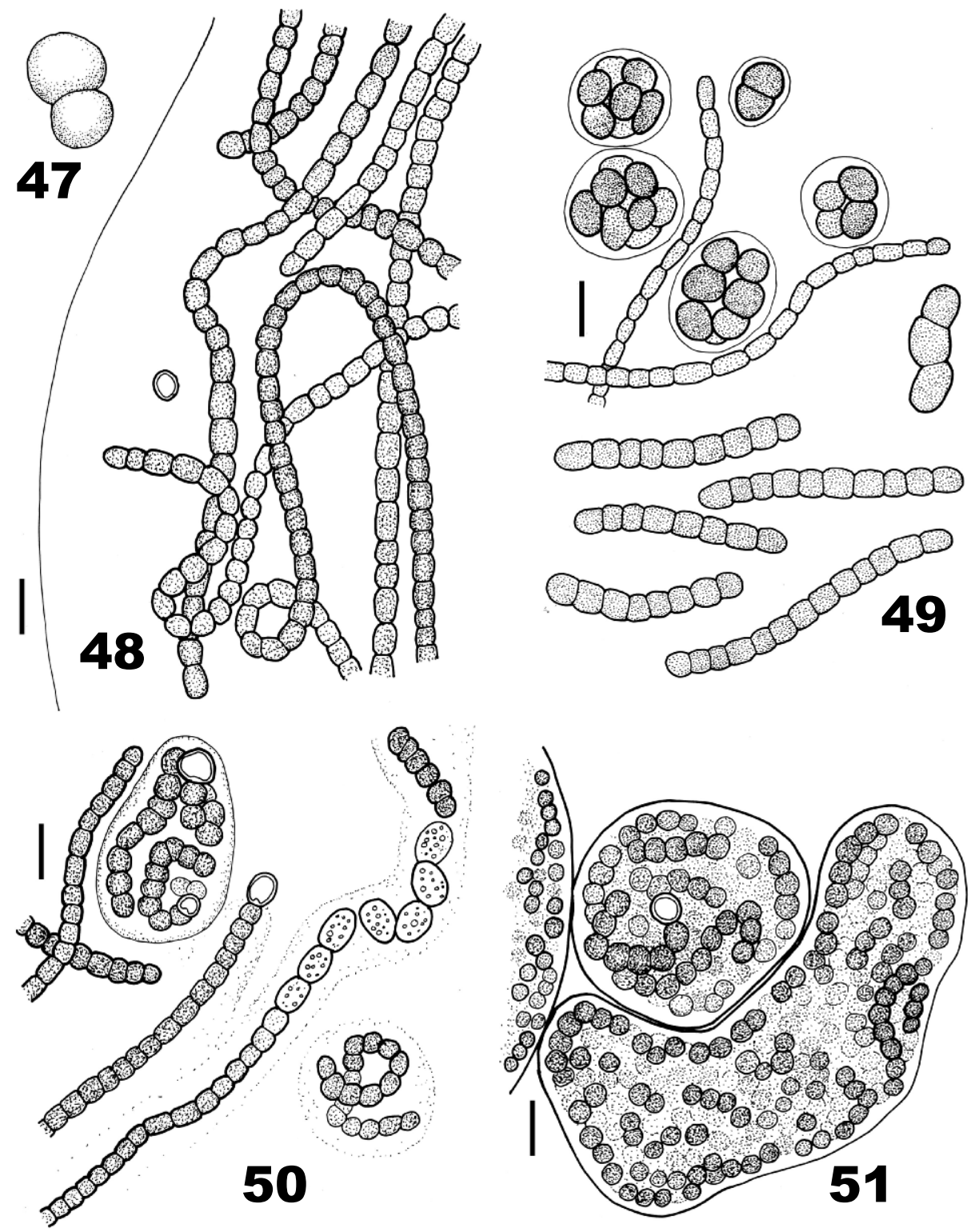

Figs. 47-51. Nostoc, Nostocineae (scale bar $=10 \mu \mathrm{m}$ ). Fig. 47. Nostoc borneti colonies. Fig. 48. Nostoc borneti. Fig. 49. Nostoc desertorum. Fig. 50. Nostoc paludosum with soft sheath. Fig. 51. Nostoc punctiforme.

colorless, eventually becoming yellow. Trichomes sometimes motile, unconstricted to slightly constricted at the crosswalls, 8-10 $\mu \mathrm{m}$. Cells blue-green, granular, isodiametric to longer than wide, $10-28 \mathrm{vm}$. Heterocytes yellowish, 8-10 vm wide, 12-24 um long.

Our specimens are up to 3 times as long as wide, whereas $T$. rupestris is up to 2 times as long as wide. Otherwise our specimens are a good fit morphologically. Unfortunately, we do not have images of the apices to see if they have meristematic zones of cells one-half to one-third as long as wide. This taxon was described from wet rocks in North America.

Trichormus variabilis (Kütz. ex Born. et Flah.) Kom. et Anag. (Fig. 54)

Colony blue green, diffuse, with satellites of hormogonia. Filaments not evidently encased 

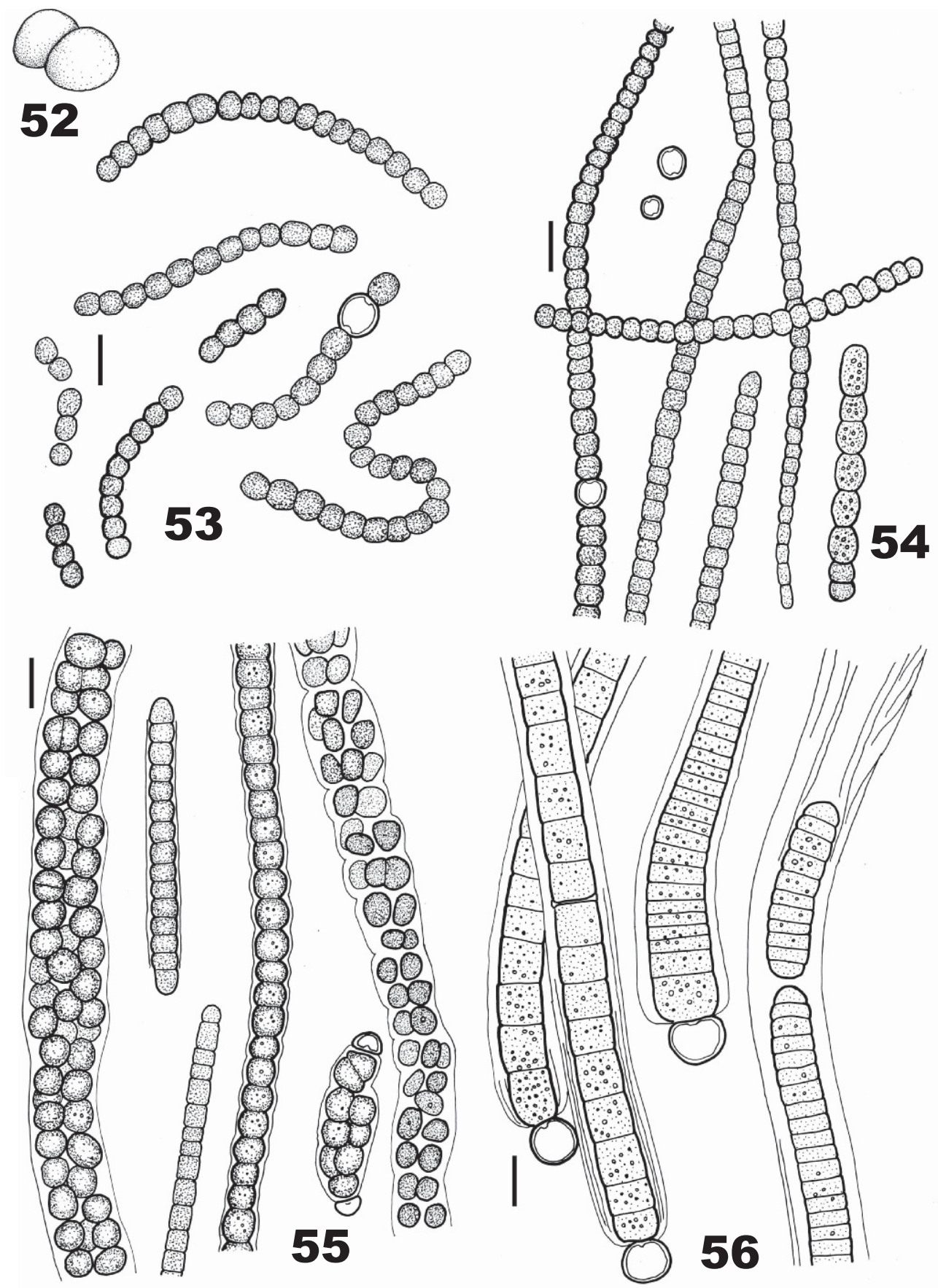

Figs. 52-56. Nostocineae (scale bar $=10 \mu \mathrm{m}$ ). Fig. 52. Nostoc sphaericum colonies. Fig. 53. Nostoc sphaericum trichomes widely dispersed in mucilage. Fig. 54. Trichormus variabilis with no mucilage. Fig. 55. Chlorogloeopsis fritschii. Fig. 56. Microchaete terrestre. 

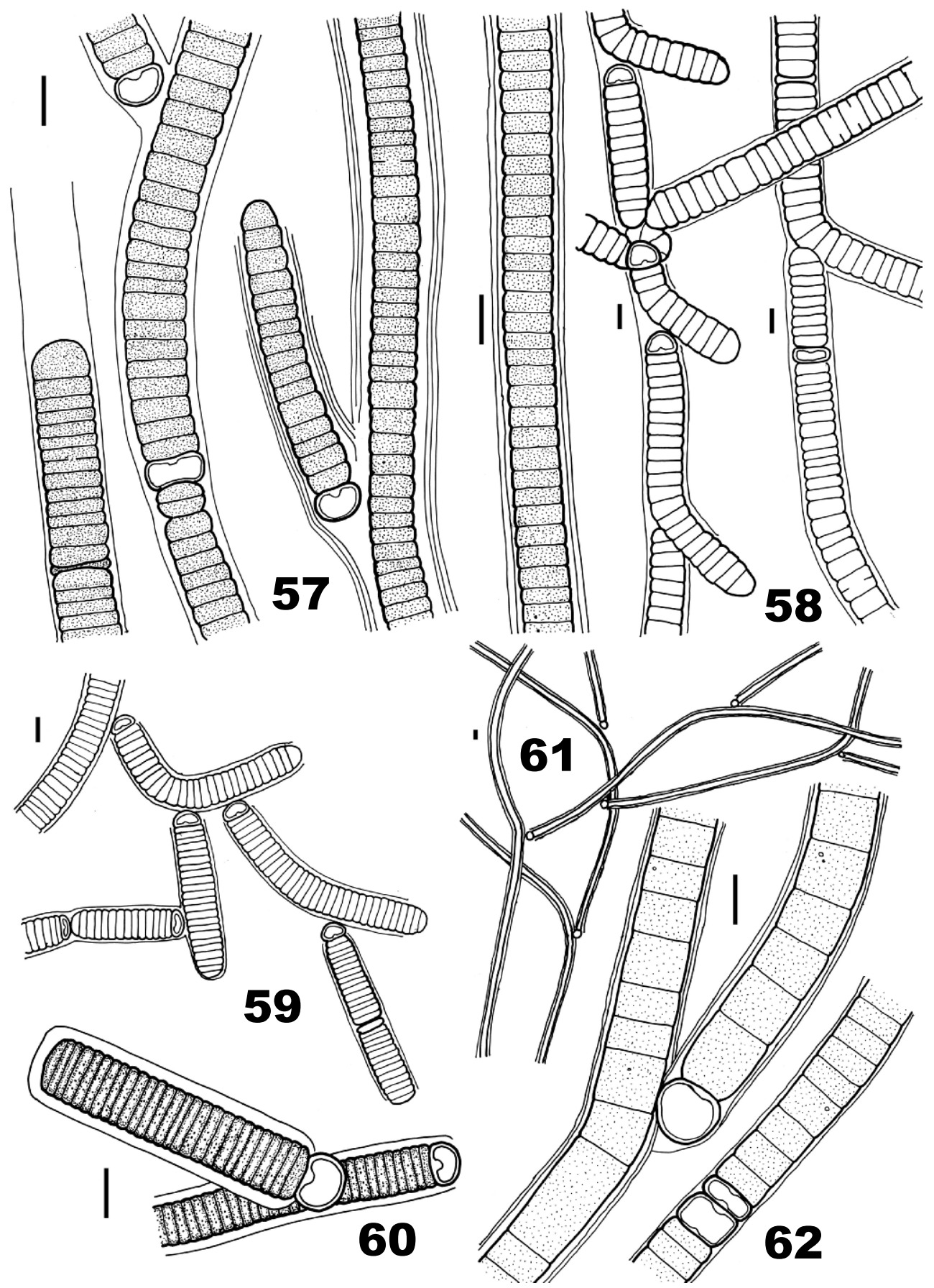

Figs. 57-62. Nostocineae (scale bar $=10 \mu \mathrm{m}$ ). Figs. 57-58. Hassallia pseudoramosissima. Figs. 59-60. Hassallia californica. Figs. 61-62. Tolypothrix distorta var. symplocoides. 

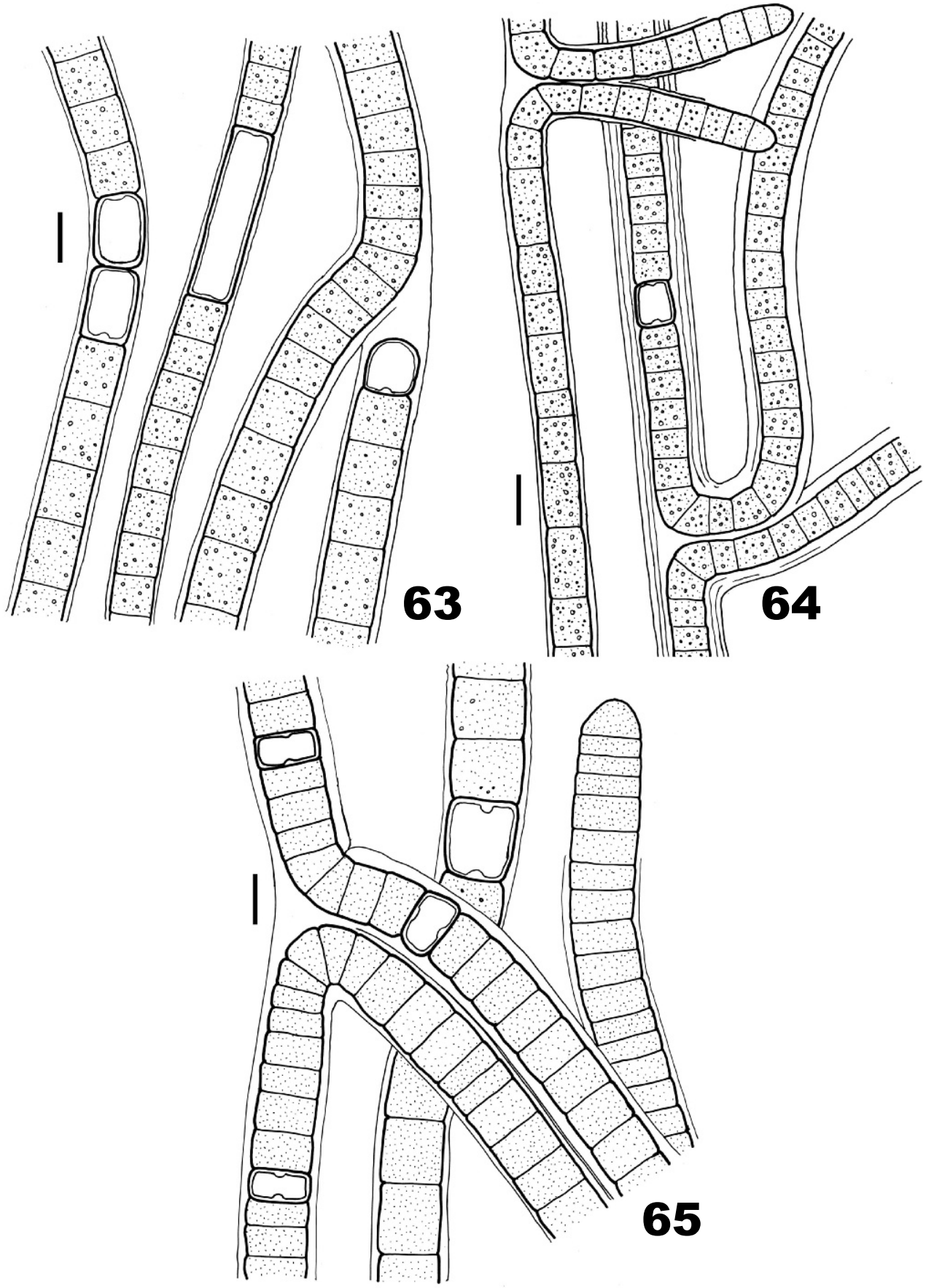

Figs. 63-65. Nostocineae (scale bar $=10 \mu \mathrm{m}$ ). Fig. 63. Tolypothrix rupestris. Fig. 64. Scytonema ocellatum. Fig. 65. Scytonema obscurum var. terrestre. 


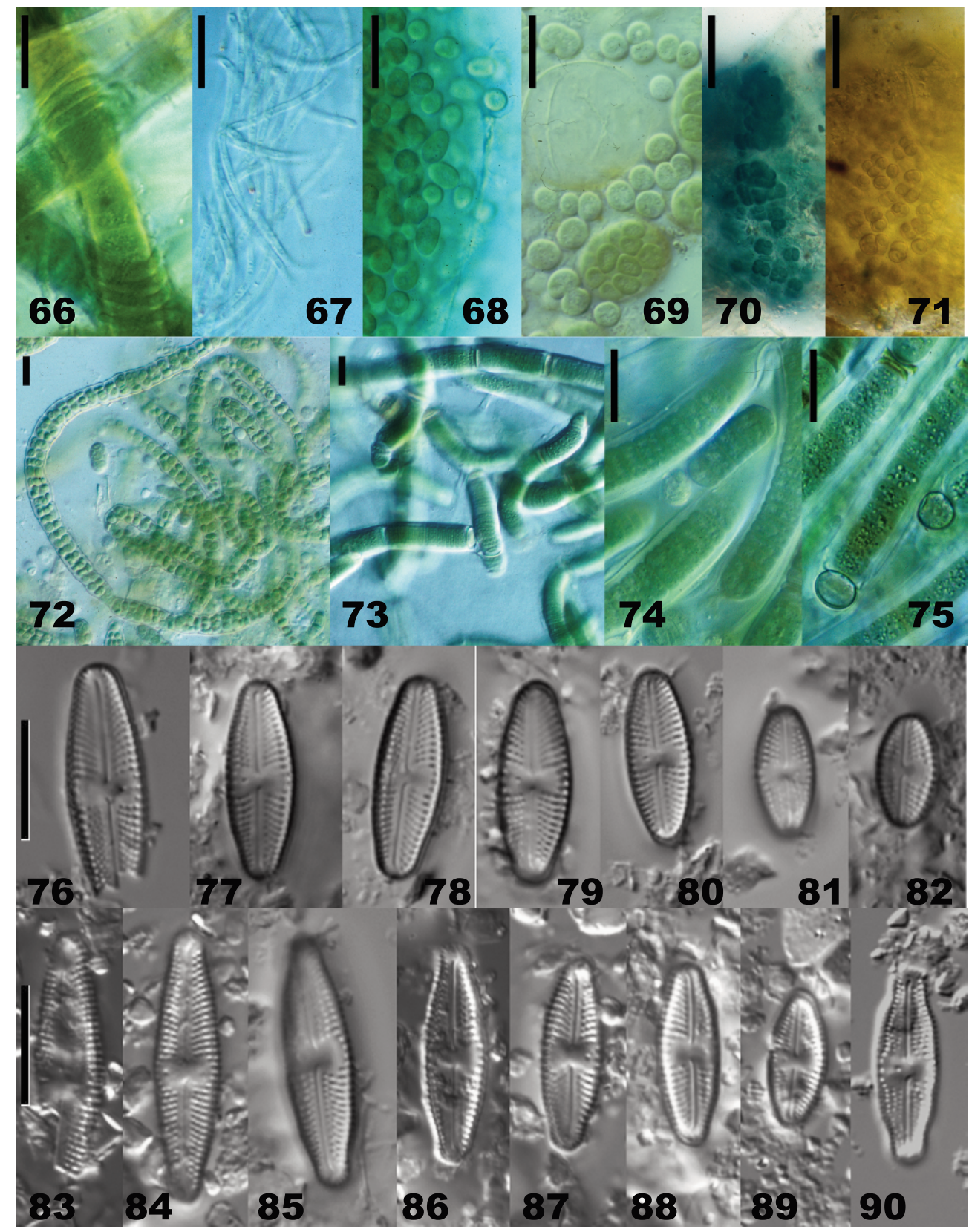

Figs. 66-75. Cyanobacteria and diatoms (scale bar $=10 \mu \mathrm{m}$, bar applies to all diatoms in the same row). Fig. 66 . Leibleinia edaphica on Tolypothrix distorta var. symplocoides. Fig. 67. Leptolyngbya sp. 4, note reddish granules in apical cells. Fig. 68. Aphanothece maritima. Fig. 69. Chroococcidiopsis edaphica, note forming baeocytes, remnant cell wall after baeocyte release, as well as released baeocytes. Fig. 70. Cyanosarcina atroveneta. Fig. 71. Gloeocapsa biformis, with yellow sheath material. Fig. 72. Chlorogloeopsis fritschii showing exceptionally long filaments. Fig. 73. Hassallia californica. Fig. 74. Hassallia pseudoramosissima. Fig. 75. Microchaete terrestre. Figs. 76-82. Luticola mutica. Figs. 83-89. Luticola cf. dismutica. Fig. 90. Luticola nivalis. 


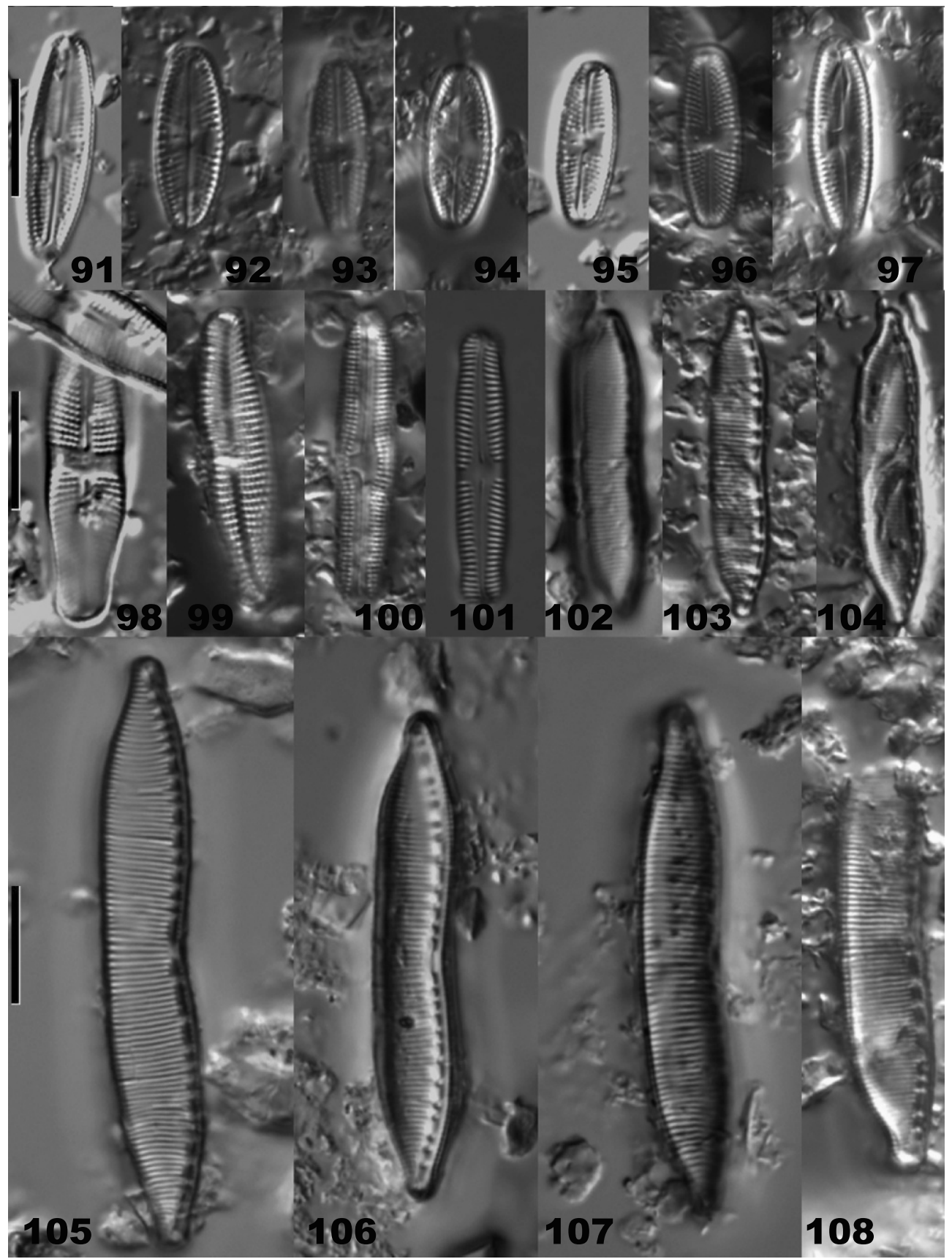

Figs. 91-108. Diatoms (scale bar $=10 \mu \mathrm{m}$, bar applies to all diatoms in the same row). Figs. 91-97. Luticola mutica, variants from nominate variety. Figs. 98-99. Achnanthes coarctata, raphe and rapheless valves. Fig. 100. Muelleria cf. gibbula. Fig. 101. Pinnularia sp. Figs. 102-104. Hantzschia amphioxys. Figs. 105-108. Hantzschia abundans. 
in mucilage. Trichomes straight or curved, entangled, constricted at the crosswalls, 2.5-3.5 $\mu \mathrm{m}$ wide. Vegetative cells roughly barrel shaped, with peripheral chromatoplasm, with 1-3 minute granules in the centroplasm, 2.4 $\mu \mathrm{m}$ long to isodiametric. Akinetes in series, minutely granular, $4-6 \mu \mathrm{m}$ wide, up to $6 \mu \mathrm{m}$ long. Heterocytes observed by us detached from the trichome, clear, $3 \mu \mathrm{m}$ in diameter.

Trichomes and cells with smaller dimensions than mentioned for this species (as Anabaena variabilis Kütz. ex Born. et Flah.) in Geitler (1930-1932) and Starmach (1966).

\section{Discussion}

For over 2 decades we have worked individually and collaboratively to characterize the microalgal taxa present in soil crust communities from a variety of arid and semiarid habitats with respect to taxon diversity within sites and floristic similarities between sites (Johansen et al. 1981, 1993, Ashley et al. 1985, Flechtner et al. 1998, Flechtner, 1999, 2007, Hawkes and Flechtner 2002, Lewis and Flechtner 2002, 2004). During the last 15 years, 2 of us (V.R. Flechtner and J.R. Johansen) have conducted floristic studies on over 30 different locations spread over the Chihuahuan, Sonoran, Mojave, Great Basin, and Colorado deserts. One goal of this research was to compare the prokaryotic and eukaryotic microalgal flora of many sites to determine which (if any) algae are common to the sites and to what extent each site has a unique flora. These studies have led to the identification of new cyanobacterial genera (Flechtner et al. 2002, Reháková et al. 2007) and new eukaryotic algal species (Flechtner et al.1998, Lewis and Flechtner 2002, 2004). Our success in documenting diversity is possible because we (1) collected composite soil samples from multiple subsites to minimize the impact of microheterogeneity in microbial distribution (Grondin and Johansen 1993), (2) obtained clonal isolates on agar solidified plates, and (3) used a multiphasic approach that included light microscopy, electron microscopy, the study of life-cycle history, and molecular techniques. Taxonomic lists of the green algae identified at these sites are posted on the Biotic Crust Project web site (available from: http://hydrodictyon.eeb.uconn.edu/bcp/).

This study provided our first opportunity to examine the microalgal flora of a site sepa- rated from the mainland by the ocean. The microheterogeneity of microalgal distribution reported in other studies (Grondin and Johansen 1993) was also observed at this site. A cyanobacterial flora rich in filamentous forms and less frequently observed coccoid forms characterized these sites. The prevalence of cyanobacteria results, at least in part, from the nonacidic nature of the soils. We encountered a number of cyanobacterial isolates that may be species new to science, and we have described 7 of them. Two newly identified species fall into the genus Hassallia, which is characterized by more or less unilateral branching and cells which are always shorter than wide and are uniform along the trichome (Komárek and Anagnostidis 1989). The species differ from each other with respect to size, frequency of branching, and ecology. Hassallia is similar to the genera Microchaete, Tolypothrix, and Scytonema in that all 3 genera are filamentous, form heterocytes, and are capable of false branching; we have observed members of these genera in several mainland sites (Flechtner 1999).

We isolated 5 taxa that key to the genus Leptolyngbya but do not fit previously described species, although 2 are sufficiently similar to described species to bear "cf." designations. Leptolyngbya is a particularly problematic cyanobacterial genus (Komárek and Anagnostidis 2005). Examination of numerous soil strains has demonstrated a paucity of morphological characters, yet considerable genetic diversity (Casamatta et al. 2005, Johansen and Casamatta 2005). We are in the process of naming new species within subaerophytic members of the genus (Johansen et al. 2008) but have not yet started the naming process among our desert strains because of the high diversity of species, the high probability of multiple genera being split out from the genus, and the limiting number of sequences for the clade. In this paper we have avoided describing new taxa in this genus until further molecular characterization and revision in the genus is completed.

Palmellopsis californica is a new species of algae in which individual cells have a gelatinous sheath and are collectively embedded in a gelatin layer. The genera Palmellopsis and Chlamydocapsa are both characterized by ovoid or coccid cells surrounded by individual gelatinous sheaths and embedded in a common 
gelatin matrix. They differ in the nature of the individual sheath, which is layered in Chlamydocapsa and unlayered in Palmellopsis. Few terrestrial species are described in either genus. Members of both these genera share characteristics with the genus Chlamydomonas, and we feel that the differentiation among these genera is problematic. The genus Chlamydomonas is currently undergoing revision (Pröschold et al. 2001), and the changes may impact the status of these genera.

Pseudotetracystis compactis was prevalent in San Nicolas Island soil; multiple isolates were found in sites $1,4,5$, and 6 . Our assignment of this isolate to the genus Pseudotetracystis rather than the morphologically similar genus Chlorosarcinopsis is based on the observations of multiple generations remaining bound by a common cell wall (Fig. 3). It differs from Pseudotetracystis terrestris, the only other known species in this genus on the basis of smaller size of vegetative cells and zoospores. Similar taxa have been identified in mainland sites (V.R. Flechtner unpublished data).

The isolation of the tribophyte Heterococcus pleurococcoides was surprising. Individually and collectively, Johansen and Flechtner have examined microbiotic crusts from over 70 sites throughout the western United States and Mexico. Prior to this work, they have each observed Heterococcus species in only 2 locations: one in Washington State (Johansen et al. 1993) and one in Utah (V.R. Flechtner unpublished data). Similarly the San Nicolas Island site is the only location to date in which Coccobotrys verrucariae has been identified.

The plasticity displayed by some alga taxa made identification using morphological criteria difficult (e.g., Trainor 1991). For example, we noted that freshly isolated cultures of $\mathrm{Di}$ plosphaera chodatii grew as clumps composed of groups of cells growing as tetrads; pigmentation was obviously olive green and brown debris adhered to the surface of the cells (Fig. 8). During subsequent passages the cultures contained primarily single cells and pairs, and were pale in color (Figs. 9, 10), resembling Stichococcus chlorelloides (Fig. 12). Plasticity was also observed in several isolates identified as members of the genus Myrmecia. In this case it is possible that morphological changes observed during subculturing occurred, as the algal strain was isolated away from a fungal partner with which it had been associated in a lichenized partnership. In cases such as these, determining the species diagnosis of an isolate often requires molecular data.

The diatom flora was unusual in comparison to that observed in other studies of biological soil crusts. Achnanthes coarctata was abundant in 2 of the samples but has always been very rare in other studies. The unidentified Muelleria and Pinnularia taxa were very rare and different from taxa previously seen in soils. To our knowledge, this is the first report of Muelleria from semiarid soils. The soils were also unusual because of the absence of Luticola cohnii (Hilse) D.G. Mann and Pinnularia borealis Ehr., taxa almost universally reported in other studies of North American arid and semiarid soils (Johansen et al. 1981, 1982, 1984, 1993, Ashley et al. 1985, Johansen and Rushforth 1985). Luticola cf. dismutica is likely a new species but was not described due to a paucity of material. This is the first report of Hantzschia abundans from desert crusts in North America, but this taxon was only recently separated from H. amphioxys, so it may be more widespread than is currently thought.

There are very few studies published since 1980 that provide complete floristic analysis of sites in North America. Floristic studies prior to 1980 (e.g., Cameron 1960, 1964) provide some useful data, but they are problematic for several reasons. First, little attention is paid to nondiatom eukaryotic algae. Second, classification of both cyanobacteria and eukaryotic algae has undergone substantial revision. As a result, studies that list flora without photographs or descriptions include species names that are no longer valid (e.g., Johansen et al. 1982, 1993). Third, the photographs published in older works are often of poor quality, making comparisons with our taxa difficult. Fourth, few publications contain written descriptions of isolates. We have found that there is considerable confusion in the literature over some taxa that are fairly common in soils. The confusion arises from several sources, including the morphological plasticity which exists for at least some species (e.g., Trainor 1991). For example, the organism identified in this study as Diplosphaera chodatii is small; grows singly, as pairs, or in packets; and has a parietal chloroplast with a naked pyrenoid, which is easy to miss unless cells are stained with iodine. Taxa with similar characteristics are designated in the earlier literature as Protococcus. 
Desmococcus chodatii is also morphologically similar to the vegetative cells of members of the genus Desmococcus. The latter genus is distinguished by the production of zoospores and sporangia with a bumpy surface. One of the most complete studies done on microdistribution of algae in crusts is $\mathrm{Hu}$ et al. (2003), but that work was done in the Tengger Desert, Ningxia Hui Autonomous Region of China, and no descriptions accompany the floristic lists. Attempting to draw conclusions concerning the similarity of our flora to that in $\mathrm{Hu}$ et al. (2003) is therefore problematic.

We can, however, make some statements concerning the similarities among the algal flora at mainland sites as reported by our group and other researchers. Klebsormidium flaccidum has been reported in multiple mainland desert sites in California, New Mexico, Utah, and Baja California, Mexico (Flechtner et al. 1998; Biotic Crust Project, http://hydrodictyon .eeb.uconn.edu/bcp/). This species was also identified in study sites in China ( $\mathrm{Hu}$ et al. 2003), Washington (Johansen et al. 1993), and Florida (Hawkes and Flechtner 2002). Based on this work, K. flaccidum appears to be a cosmopolitan crust species, but without molecular data it is impossible to know how closely these geographically separate strains are related. Similarly, one or both of the isolates identified as Stichococcus bacillaris and Stichococcus chlorelloides were also encountered frequently in these sites and it appears that these taxa are widely distributed in microbiotic crusts. Molecular studies would be necessary to determine how similar these isolates are to each other. These taxa are only some examples of algal taxa that are widely distributed in desert soil crusts. Microcoleus vaginatus, Nostoc punctiforme, Tolypothrix distorta, Luticola mutica, and Hantzschia amphioxys are similarly widespread and abundant.

Two other genera show a different distribution pattern. The most thoroughly characterized new species of eukaryotic algae isolated from San Nicolas Island, S. deserticola, is 1 of 3 cryptic species in the Scenedesmus obliquus (Turp.) Kütz. complex isolated from desert soils (Lewis and Flechtner 2004). Based on $18 \mathrm{~S}$ rRNA sequence data, this isolate, along with 7 morphologically similar taxa from 5 geographically distinct crusts, formed 2 loose clusters within the genus Scenedesmus. These organisms resolved into 2 distinct monophyletic clades when the internal transcribed spacer (ITS) region was used for the phylogenetic analysis. One clade included the isolate from San Nicolas Island and 4 additional isolates from Arizona, New Mexico, and California (see Lewis and Flechtner 2004). These strains were placed in a single species designated $S$. deserticola. The 2nd clade contained 3 isolates from Baja California, Mexico; these strains were placed in the species S. bajacalifornicus Lewis et Flechtner. The eustigmatophyte Eustigmatos magnus has thus far been reported in only 2 sites: Baja California, Mexico (V.R. Flechtner unpublished data) and San Nicolas Island; multiple isolates were obtained at each site. These observations support the view that there is considerable diversity in the microalgal flora present in microbiotic crusts from different geographic regions.

What can we say about the abiotic factors that influence the algal species composition of crusts? The effect of chemical and physical soil properties on the distribution of algal species across 10 sites in Baja California, Mexico, revealed no clear connection between algal species distribution and soil characteristics for any factor except $\mathrm{pH}$ (Flechtner et al. 1998). Similar results have been obtained for sites in Utah (J.R. Johansen and V.R. Flechtner, unpublished data) and California (Johansen et al. 2001). Consistent with the findings of others, our findings show that cyanobacterial taxa occurred at highest frequency in soils with $\mathrm{pH}$ above 7.0. The $\mathrm{pH}$ of the 10 sites in the Baja study ranged from 6.3 to 7.7 , with a more diverse cyanobacterial flora in alkaline sites (pH 7.3 and 7.7) than in the more acidic sites (pH 6.3-6.9; Flechtner et al. 1998). The pH of the 7 sites on San Nicolas Island ranged from 7.7 to 8.3. The fact that these sites were more alkaline than the Mexico sites likely explains, at least in part, the finding that the cyanobacterial flora from the San Nicolas Islands was more abundant and more diverse than that of the Mexico site. Eighteen taxa from 8 cyanobacterial genera were described from the Mexico site, while 32 taxa from 19 cyanobacterial genera were described in this study. Though members of the genus Nostoc were prevalent at both sites, filamentous heterocyteforming taxa (Hassallia, Scytonema, Tolypothrix) were found in greater abundance on San Nicolas Island than in Mexico, while Microcoleus spp. were more prevalent in the Mexico 
site. Comparable data are not available from other mainland sites. In another study in the Mojave Desert, Johansen and coworkers (Johansen et al. 2001) found that cyanobacterial distribution and abundance were not tied to soil chemical parameters, although diversity and abundance were depressed by anthropogenic disturbance. The limitation of all of these studies is that soil chemistry may not vary significantly among sites within a given study. Furthermore, when comparisons are made among widely spaced sites, climatic and geological differences among the sites likely mask differences due to soil chemistry.

Algae can be dispersed among sites by biotic forces (animals) and abiotic forces (wind). One might assume that sites that are closer together would be more likely to receive algal propagules by prevailing winds than sites that are farther apart. To test this assumption, we compared the algal flora of San Nicolas Island with that of mainland sites in Arizona, California, New Mexico, and Baja California, which we have studied (Flechtner et al. 1998, unpublished data). San Nicolas Island lies about 270 miles west of the Yuma, Arizona, and San Bernadino, California, sites, about 360 miles northwest of the Baja California site and about 786 miles southwest of the Otero, New Mexico, site. Assuming that prevailing winds would blow predominantly east and south of the island, one might expect to see dispersion of San Nicolas taxa to the Arizona, California, and Mexico sites more easily than dispersion to the New Mexico site. Our results do not bear out this expectation. Scenedesmus deserticola was isolated from sites on San Nicolas Island and in Arizona, California, and New Mexico; a different species, Scenedesmus bajacalifornicus, was identified at the Baja site. An even more dramatic finding is that the algal flora most similar to that of Baja California was identified in soils from rosemary scrub sites at Archibold Biological Station, which is in Highlands County, Florida, 2200 miles east of the Mexico site (Flechtner et al. 1998, Hawkes and Flechtner 2002). These sites shared several algal taxa including the 2 new taxa Cylindrocystis brebissonii var. deserti Flechtner et Johansen and the newly described species Elakatothrix obtusa Flechtner et Johansen, which have not been observed in any other sites. Thus geographical proximity of study sites does not necessarily correlate with similarity in algal flora.
Although some researchers (e.g., Finlay 2002) maintain that most eukaryotic microorganisms are cosmopolitan, we do not agree. This study is part of a growing body of work that suggests that rich algal diversity and numerous taxa new to science exist in desert soils. It is our experience that study sites must be extensively sampled and that a polyphasic approach that includes observational and molecular methods is required to detect the microbial diversity that exists in soils.

Understanding the extent and nature of this diversity is of interest to systematists and ecologists. Using molecular phylogenetic analyses, Lewis and Lewis (2005) demonstrated that in some cases desert lineages appear to have no close aquatic relatives, and their research addressed the potential importance of these lineages in the evolution of green algae. As scientists continue to probe the importance of microbiotic crusts to the ecosystem, knowledge of the algal components comprising these crusts becomes increasingly important. Ecosystem processes, such as nitrogen fixation, carbon fixation, soil adhesion, water retention, and recovery following disturbance, are all possibly affected by the particular microbial communities that inhabit the soil. As we more clearly understand the elaborate species diversity present, we may also begin to understand the subtle differences among the contributions these taxa make to such ecosystem processes.

\section{ACKNOWLEDGMENTS}

We thank Dr. Bruce Webb of the Soil Chemistry Testing Laboratory at Brigham Young University for conducting the soil chemistry analyses, and we also thank 2 anonymous reviewers, whose comments helped us improve this manuscript. The Zeiss Axioskop microscope was purchased in part with funds from NSF BIR-9319239. John Carroll University provided support for supplies, research release time for V.R. Flechtner and J.R. Johansen, and a Grauel Fellowship to V.R. Flechtner. Field assistance was provided by Sue Phillips, Danielle Foster, and Cynthia Furman, and funds for field work were provided by the Department of Defense Legacy Fund.

\section{Literature Cited}

Arneson, R.D. 1973. Pseudotetracystis, new Chlorosarcinacean alga. Journal of Phycology 9:10-14. 
Ashley, J., S.R. Rushforth, and J.R. Johansen. 1985. Soil algae of cryptogamic crusts from the Uintah Basin, Utah, U.S.A. Great Basin Naturalist 45:432-442.

Bhatnagar, A., and M. Bhatnagar. 2005. Microbial diversity in desert ecosystems. Current Science 89:91100.

BoLd, H.C., AND M.J. Wynne. 1978. Introduction to the algae. Prentice-Hall, Inc., Englewood Cliffs, NJ.

Cameron, R.E. 1960. Communities of soil algae occurring in the Sonoran Desert in Arizona. Journal of Arizona Academy of Science 1:85-88.

1964. Algae of southern Arizona II. Algal flora (exclusive of blue-green algae). Revue Algologique 7:151-177.

CARMichael, W.W. 1986. Isolation, culture, and toxicity testing of toxic freshwater cyanobacteria (blue-green algae). Pages 1249-1262 in V. Shilov, editor, Fundamental research in homogenous catalysis. Volume 3. Gordon \& Breach, New York.

Casamatta, D.A., J.R. Johansen, M.L. Vis, and S.T. BroadWATER. 2005. Molecular and ultrastructural characterization of ten polar and near-polar strains within the Oscillatoriales (Cyanobacteria). Journal of Phycology 41:421-438.

Desikachary, T.V. 1959. Cyanophyta. Indian Council of Agricultural Research, New Delhi.

ETTL, H. 1978. Xanthophyceae I. In: H. Ettl, J. Gerloff, and H. Heynig, editors, Süsswasserflora von Mitteleuropa, Bd. 3, Gustav Fischer Verlag, Stuttgart, Germany.

EtTl, H., AND G. GärTner. 1995. Syllabus der BodenLuft-, und Flechtenalgen. Gustav Fischer Verlag, Stuttgart, Germany.

FinLAY, B. 2002. Global dispersal of free-living microbial eukaryotic species. Science 296:1061-1063.

Flechtner, V. 1999. Enigmatic desert soil algae. Pages 231-241 in J. Seckbach, editor, Enigmatic microorganisms and life in extreme environments. Kluwer Academic Publishers, The Netherlands.

2007. North American desert microbiotic soil crust communities: diversity despite challenge. Pages 539551 in J. Seckbach, editor, Algae and cyanobacteria in extreme environments. Springer, The Netherlands.

Flechtner, V.R., S.L. Boyer, J.R. Johansen, and M.L. DeNoBLE. 2002. Spirirestis rafaelensis gen. et sp. nov. (Cyanophyceae), a new cyanobacterial genus from arid soils. Nova Hedwigia 74:1-24.

Flechtner, V.R., J.R. Johansen, AND W.H. Clark. 1998 Algal composition of microbiotic crusts from the Central Desert of Baja California, Mexico. Great Basin Naturalist 5:295-311.

Flechtner, V.R., R.A. NG, J.R. Johansen, and S. Antonio. 2005. Algal diversity in North American desert soils. Pages 1-9 in R.B. Hoover, G.V. Levin, A.Y. Rozanov, and G.R. Gladstone, editors, Astrobiology and planetary missions. Proceedings of SPIE, Volume 5906 (2).

Geitler, L. 1930-1932. Cyanophyceae. In: L. Rabenhorst, editor, Krytogamen-Flora von Deutschland, Österreich und der Schweiz. Reprinted 1985, Koeltz Scientific Books, Königstein, Germany.

Grondin, A., AND J.R. Johansen. 1993. Microbial spatial heterogeneity in microbiotic crusts in Colorado National Monument. I. Algae. Great Basin Naturalist 53:24-30.

Hawkes, C.V., AND V.R. FleChtNer. 2002. Biological soil crusts in a xeric Florida shrubland: composition, abundance, and spatial heterogeneity of crusts with different disturbance histories. Microbial Ecology 43:1-12.

HibBERD, D.J. 1981. Notes on the taxonomy and nomenclature of the algal class Eustigmatophyceae and Tribophyceae (synonym Xanthophyceae). Botanical Journal of the Linnean Society 82:93-119.

Hoffmann, L., J. KomáRek, and J. KašTovskÝ. 2005. Proposal of cyanobacterial system-2004. Pages 657660 in J. Komárek and K. Anagnostidis, editors, Süßwasserflora von Mitteleuropa Cyanoprokaryota 19/2 2nd part: Oscillatoriales. Spektrum Akademischer Verlag. Elsevier GmbH, München, Germany.

Hu, C., D. Zhang, Z. Huang, and Y. Liu. 2003. The vertical micro-distribution of cyanobacteria and green algae within desert crusts and the development of algal crusts. Plant and Soil 257:97-111.

HustedT, F. 1961-1966. Die Kieselalgen Deutschlands, Österreichs und der Schweiz, Teil 3. Pages 1-816 in Rabenhorst's Kryptogammen-Flora von Deutschland, Österreich und der Schweiz. Reprinted 1977, Otto Koeltz Science Publishers, Koenigstein, Germany.

Johansen, J.R. 1993. Cryptogamic crusts of semiarid and arid lands of North America. Journal of Phycology 29:140-147.

Johansen, J.R., J. Ashley, and W.R. Rayburn. 1993. Effects of rangefire on soil algal crusts in semiarid shrubsteppe of the lower Columbia Basin and their subsequent recovery. Great Basin Naturalist 53:73-88.

Johansen, J.R., C. Britton, T.C. Rosati, X. Li, L.L. St. Clair, B.L. WebB, A.J. Kennedy, and K.S. Yanko. 2001. Microbiotic crusts of the Mojave Desert: factors influencing distribution and abundance. Nova Hedwigia, Beiheft 123:339-369.

Johansen, J.R., and D.A. Casamatta. 2005. Recognizing cyanobacterial diversity through adoption of a new species paradigm. Algological Studies 116:71-93.

Johansen, J.R., A. Javakul, and S.R. Rushforth. 1982. Effects of burning on the algal communities of a high desert soil near Wallsburg, Utah. Journal of Range Management 35:598-600.

Johansen, J.R., C.E. Olsen, R.L. Lowe, K. FuČíková, AND D.A. Casamatta. 2008. Leptolyngbya species from selected seep walls in the Great Smokey Mountains National Park. Algological Studies 126:21-36.

Johansen, J.R., AND S.R. Rushforth. 1985. Cryptogamic soil crusts: seasonal variation in algal populations in the Tintic Mountains, Juab County, Utah, U.S.A. Great Basin Naturalist 45:14-21.

Johansen, J.R., S.R. Rushforth, and J.D. Brotherson. 1981. Subaerial algae of Navajo National Monument, Arizona. Great Basin Naturalist 41:433-439.

Johansen, J.R., L.L. St. Clair, B.L. Webb, and G.T. NEBEKER. 1984. Recovery patterns of cryptogamic soil crusts in desert rangelands following fire disturbance. Bryologist 87:238-243.

KantZ, T., AND H. BoLD. 1969. Morphological and taxonomic investigations of Nostoc and Anabaena in culture. Phycological Studies IX. University of Texas Publication 6924.

KomáReK, J., And K. Anagnostidis. 1989. Modern approach to the classification system of Cyanophytes 4 - Nostocales. Algological Studies 56:247-345.

1998. Cyanoprokaryota 1. Teil: Chroococcales. Pages 1-548 in H. Ettl, G. Gärtner, H. Heynig, and D. Mollenhauer, editors, Süßwasser-Flora von Mitteleuropa. Gustav Fischer Verlag, Jena, Germany. 
2005. Cyanoprokaryota 2. Teil: Oscillatoriales Pages 1-758 in H. Ettl, G. Gärtner, H. Heynig, and D. Mollenhauer, editors, Süßwasser-Flora von Mitteleuropa. Gustav Fischer, Jena, Germany.

Komárek, J., And B. Fott. 1983. Chlorococcales. Pages 1-1043 in G. Huber-Pestalozzi, editor, Das Phytoplankton des Süßwassers. Volume 7. Schweizerbart, Stuttgart, Germany.

LEwIS, L.A. 2007. Chlorophyta on land: independent lineages of green eukaryotes from arid lands. Pages 571582 in J. Seckbach, editor, Algae and cyanobacteria in extreme environments. Springer, The Netherlands.

LEWIS, L.A., AND V.R. Flechtner. 2002. Green algae (Chlorophyta) of desert microbiotic crusts: diversity of North American taxa. Taxon 51:443-451.

2004. Cryptic species of Scenedesmus (Chlorophyta) from desert soil communities of western North America. Journal of Phycology 40:1127-1137.

LEWIS, L.A., AND P.O. LEWIS. 2005. Unearthing the molecular phylodiversity of desert soil green algae (Chlorophyta). Systematic Biology 54:936-947.

Metzeltin, D., H. Lange-Bertalot, and F. GarcíaRoDríGuez. 2005. Diatoms of Uruguay. Iconographia Diatomologica 15:1-736.

Pröschold, T., B. Marin, U.G. Schlösser, and M. MelKonian. 2001. Molecular phylogeny and taxo- nomic revision of Chlamydomonas (Chlorophyta). I. Emendation of Chlamydomonas Ehrenberg and Chloromonas Gobi, and description of Oogamochlamys gen. nov. and Lobochlamys gen. nov. Protist 152:265-300.

Řeháková, K., J.R. Johansen, D.A. Casamatta, X. Li, and J. Vincent. 2007. Morphological and molecular characterization of selected desert soil cyanobacteria: three species new to science including Mojavia pulchra gen. et sp. nov. Phycologia 46:481-502.

Schmidt, A. 1874-1959. Atlas der Diatomaceen-Kunde. Reprinted 1984, Koeltz Scientific Books, Koenigstein, Germany. 480 plates.

Simonsen, R. 1987. Atlas and catalogue of the diatom types of Friedrich Hustedt. Volume 3, plates 396-772. J. Cramer, Berlin, Germany.

Starmach, K. 1966. Flora słodkowodna Polski. Tom 2. Państwowe Wydawnictwo Naukowe, Warszawa.

Trainor, F.R. 1991. Scenedesmus plasticity: facts and hypotheses. Journal of Phycology 27:555-556.

Watanabe, S. 1983. New and interesting green algae from soils of some Asian and Oceanian regions. Archiv für Protistenkunde 127:223-270.

Received 9 May 2007 Accepted 18 April 2008 